\title{
О СЕРГЕЕ РАДЛОВЕ И ОСИПЕ МАНДЕЛЬШТАМЕ (ПО АРХИВНЫМ ИСТОЧНИКАМ)'
}

\author{
М. Г. Сальман \\ (С.-Петербург)
}

Цель нашей работы - ввести в научный оборот новые данные об О. Э. Мандельштаме и театральном режиссере С. Э. Радлове. В статье сообщается также о неизвестном прежде факте совместного выступления Мандельштама и Н. С. Гумилева и приводятся сведения, позволяющие по-новому взглянуть на шуточную пьесу «Кофейня разбитых сердец».

Имя Радлова много лет оставалось в тени, в Театральной энциклопедии о нем сказано в нескольких строчках, и приведена неверная дата рождения (см.: ТЭ 1965, IV: 514). Лишь за последнее время появились специально посвященные ему работы, такие как монография Д. И. Золотницкого (см.: Золотницкий 1999), статья и книга В. М. Гайдабуры (см.: Гайдабура 1992: 101-126; Гайдабура 2009, последняя вышла на украинском языке, здесь в переводе опубликованы лагерные письма Радлова и его жены). Необходимо упомянуть публикацию П. В. Дмитриева (см.: Радлов 1994: 80-101), статьи В. Е. Кельнера (см.: Кельнер 2006: 163-184) и Б. А. Равдина (см.: Равдин 2012: 180-202).

Имя режиссера встречается у исследователей, пишущих о М. А. Кузмине 1920-1930-х (см.: Богомолов, Малмстад 2013; Куранда 2015: 226-270; Куранда 2016: 89-96), у публикаторов писателя, как Г. А. Морев (см.: Кузмин 2007) и С. В. Шумихин (см., напр.: Шумихин

\footnotetext{
1 Нам уже доводилось писать о С. Э. Радлове и О. Э. Мандельштаме, см.: Сальман 2009: 292-304. Новая статья почти не использует старый материал, она базируется на неопубликованных архивных документах ЦГИА СПб. и ОР РНБ. Все даты досоветского периода приводятся по старому стилю. Документы публикуются по правилам современной орфографии и пунктуации, сохраняется, однако, написание прописных букв. Общеизвестные имена - М. Л. Лозинского, С. М. Михоэлса, Вл. С. Соловьева, Б. В. Томашевского и т. д. - не комментируются.
} 
2015: 203-225), поскольку Кузмин много общался с Радловым в 19201930-е 2 , писал музыку для радловских постановок, посвятил ему свою последнюю пьесу «Смерть Нерона» (см.: Ботт 1989: 141-151; коррекцию к утверждениям исследовательницы см.: Богомолов 1995: 174).

В письме к С. М. Михоэлсу от 20 августа 1930 режиссер писал о себе: «<...> я родился на Васильевском острове г. Петербурга, самого не русского из всех российских городов. За всю мою жизнь с русской деревней никогда не соприкасался, проводя летние месяцы то на Кавказе, то в Финляндии. Никогда в моей жизни не приходилось мне вступать в личные взаимоотношения ни с русским помещиком, ни с русским крестьянином» (цит. по: Иванов 2009: 510).

Его отец Эрнест Леопольдович (Львович) Радлов (1854-1928) после окончания Петербургского университета служил в Публичной библиотеке, где стал специалистом по первопечатным изданиям и занялся изучением маргиналий на книгах библиотеки Вольтера. Одновременно он преподавал историю философии и логику в Александровском лицее, в Училище правоведения и на Высших женских (Бестужевских) курсах, с 1907 читал лекции в Петербургском университете. В 1899 его назначили редактором «Журнала министерства народного просвещения», а с 1 сентября 1917 до начала 1924 он исполнял должность директора Публичной библиотеки (см.: Сотрудники РНБ 1995-2003, 1: 434, 435).

Сергей Эрнестович Радлов, младший сын потомственного дворянина, надворного советника Эрнеста Леопольдовича Радлова, лютеранского вероисповедания, и законной жены его Веры Александровны Давыдовой, двоюродной сестры М. А. Врубеля ${ }^{3}$, православного вероисповедания, родился 23 сентября 1892. Крещение состоялось 11 октября, причем восприемником был поэт

\footnotetext{
2 См., напр.: «К Радловым, как на радость» (Шумихин 2015: 221); «Был Радлов с Ходасев<ич>» (Шумихин 2015: 215). Валентина Михайловна Ходасевич $(1894-1970)-$ театральный художник, мемуаристка, много работала с Радловым в 1920-е, см. его статью о ней: Радлов 1927: 19-29.

3 См.: Кельнер 2006: 95.

4 См.: ЦГИА СПб. Ф. 14. Оп. 3. Д. 56066. Л. 33. Копия. В дальнейшем при цитировании указываем только номер дела и лист.
} 
и философ, «отставной Коллежский Советник Владимир Сергеев Соловьев» ${ }^{5}$ близкий друг отца.

В 1902 Сергей Радлов поступил на гимназическое отделение Училища при евангелическо-лютеранской церкви св. Анны, где обучение шло на немецком языке, и в 1910 окончил его с серебряной медалью. В аттестате зрелости у него стояло три четверки - по математике, греческому языку и французскому (см.: Сальман 2009: 292). 4 июня 1910 он подал ректору Петербургского университета прошение о зачислении на классическое отделение историкофилологического факультета (см.: Там же).

Представление о студенческих годах Радлова можно составить себе по его письмам к старшей сестре Н. Э. Казанской ${ }^{6}$ В письме от 11 октября 1911 он так описывал свое времяпрепровождение:

5 Там же.
6 Наталья Эрнестовна Казанская (урожд. Радлова; 26 февраля 1887-1938; дату рож-
дения приводим по паспорту, выданному 18 мая 1910, см.: ОР РНБ. Ф. 1393. Ед. хр. 910. Л. 2 об. В ее трудовой книжке (см.: Там же. Ед. хр. 919. Л. 1) и в Curriculum vitae, написанном, по нашему предположению, не позднее 1924 (см.: Там же. Ед. хр. 908. Л. 1), годом рождения указан 1892, что не соответствует действительности. Дата «1886», указанная Г. А. Моревым, см.: Кузмин 2007: 353, также неверна). В 1898 она поступила во второй класс петербургской гимназии Л. С. Таганцевой и в 1904 окончила седьмой выпускной класс (см.: ОР РНБ. Ф. 1393. Ед. хр. 909. Л. 11-12). Затем училась сценическому искусству, служила актрисой в Виннице в 1911-1912 (см.: Там же. Ед. хр. 908. Л. 1), потом играла в Петербурге в Передвижном театре. Как она сама писала в Curriculum vitae, «Работала под руководством Иды Айлберг <правильно - Альберг. - M. C.>, о кот<орой> написала книжку<,> переведенную на финский и шведский языки<,> но не изданную на русском» (Там же). 29 мая 1913 вышла замуж за университетского приятеля брата, Б. В. Казанского, см.: Там же. Ед. хр. 910. Л. 4. В браке родились две дочери. Мария (1914-1942) - художница, погибла в блокаду (см.: Казанский 2012: 11; на сайте «Возвращенные имена. Блокада» указан неверный год ее рождения, см.: [http://visz.nlr.ru/blockade/10]) и Татьяна (1916-1989) - лингвист, педагог. Живя с мужем в Перми в 1917-1918, Казанская «работала в гимназиях, вела декламации» (ОР РНБ. Ф. 1393. Ед. хр. 908. Л. 1), руководила драматической студией при Народном университете. В 1919-1920 семья жила в Томске, весной 1920 переехала в Пермь, там Казанская заведовала студией (см.: Там же. Л. 1). В сентябре 1920 вернулась в Петроград, была прописана по адресу Садовая ул., 18, кв. 14 (см.: Там же. Ед. хр. 919. Л. 14). Это номер дома, национализированного в 1918 и переданного Публичной библиотеке, казенная квартира в нем была предоставлена Э. Л. Радлову как директору библиотеки. В Петрограде преподавала постановку голоса в студии Передвижного театра (см.: Там же. Ед. хр. 908. Л. 1 об). Ее ученицей была актриса Е. В. Юнгер, которая вспоминала, что 
Это странно, но<,> по-видимому<,> полное безделие лета так на меня повлияло, что захотелось работать больше, чем когда-либо. А работы<,> как всегда в таких случаях, оказывается по горло. Несколько вечеров-ночей сидели с Казанским ${ }^{7}<\ldots>$ за греческими классиками, остальное время делится между университетом, уроками, работой дома и иногда у профессоров. Стихи это время писать перестал, кто знает, может быть<,> навсегда 8 .

\section{В письме от 1 ноября 1911 к ней же:}

Н. Э. Казанская «приложила героические усилия, чтобы преодолеть природную зажатость моего голоса, чтобы он зазвучал, чтобы его было слышно» (Скорочкина 1999: 45). С 1923 преподавала в Институте живого слова, см. письмо ее давнего знакомца В. А. Пяста от 25 января 1924: «Шесть роялей с замками чинно ждут в коридоре, кишащем студенческой публикой. Надеюсь, что Вы придете. Работа будет уютная, обещает будущее. Придут и старшие студенты, и будем организовывать группы» (ОР РНБ. Ф. 1323. Ед. хр. 1098. Л. 1). Автор книги «Работа над речью», (см.: Радлова-Казанская 1930). О Б. В. Казанском см. следующее прим. Ида Андреевна Альберг (Икскуль-Гильдебранд) (1858-1915) - финская драматическая актриса. Владимир Алексеевич Пяст (настоящая фамилия Пестовский; 1886-1940) - поэт, переводчик, мемуарист. Мандельштам подарил Пясту второе издание «Камня» с инскриптом: «В. Пясту с любовью Осип Мандельштам. 21 дек. 1915» (Лукницкий 1991: 111). Подробнее см.: Лекманов 2000: 556-560; Тименчик 2008: 274-311.

7 Борис Васильевич Казанский (1889-1962) - филолог-классик, пушкинист. Окончил историко-филологический факультет Петербургского университета и был оставлен при кафедре классической филологии для приготовления к профессорскому званию. С 1913 служил в Публичной библиотеке. Летом 1917 переехал в Пермь, где числился и. д. экстраординарного профессора по кафедре классической филологии при пермском отделении Петроградского университета, см.: Табункина 2015: 139. 25 декабря 1918 в Пермь вступила армия Колчака, часть студентов была мобилизована, часть разъехалась по домам, «здания университета, кроме главного корпуса, были заняты под казармы и лазареты» (Кертман 1987: 19), и занятия во втором семестре не проводились. В июне 1919 началось наступление Красной армии, и, как вспоминал в январе 1949 один из преподавателей, «по приказу чехословацкого генерал-лейтенанта Гайда $<\ldots>$ началась эвакуация всех учреждений Перми. <...> всему университетскому личному составу было предписано пешком отступать из Перми на восток. <...> На станции Ляды нас посадили на открытые платформы (кажется, это было в первой половине июня) и мы поехали в неизвестность. <..> Ехали мы, сидя на каких-то брусках и досках, которые тоже “эвакуировались” куда-то в Сибирь. В конце концов нас привезли в Томск» (Орлов 1991: 32, 33). В Пермь из Томска Казанский вернулся весной 1920 , в Петроград - осенью, там он начал работать в ГИИИ, а затем преподавать в университете. См. о нем в воспоминаниях внука: Казанский 2012: 8-12.

8 ОР РНБ. Ф. 1393. Ед. хр. 1100. Л. 20-21 об. 
<..> Утром был в университете, во втором часу пришел домой, читал Плиния (по латыни) до 4-х, лег спать до обеда, после него опять читал Плиния, до этой минуты (9-ти часов), сейчас <..> пойду на часок в Шахм<атное> Собр<ание > посмотреть окончание большого турнира, затем<,> вернувшись домой<,> буду сидеть часов до 3-х. А сегодня еще тем спокойный день, что нет уроков. Совершенно спокойного дня, без уроков и университета $<$,> у меня нет вовсе - по воскресеньям собираемся у Зелинского?.

У Ф. Ф. Зелинского Радлов занимался в семинарии, который был посвящен трагедиям Софокла, не дошедшим до нашего времени (см.: Отчет 1914: 113 и Обозрение 1913: 5); у него же писал зачетное сочинение ${ }^{10}$. В «Отчете о состоянии и деятельности императорского Санкт-Петербургского университета за 1913 год» так охарактеризована работа студентов-классиков: представили «интересные по своим научным результатам рефераты <...> ст<удент> Радлов об «Александре» и «Паламеде». <...> доклад г. Радлова тоже предполагается напечатать» (Отчет 1914: 113).

Среди его университетских преподавателей, кроме Зелинского, необходимо назвать имена Л. В. Щербы, которому будущий режиссер сдавал введение в языкознание (см.: Сальман 2009: 293), И. А. Бодуэна-де-Куртенэ ${ }^{11}$, читавшего сравнительную фонетику и морфологию индоевропейских языков (см.: Там же), Н. О. Лосского ${ }^{12}$ (логика и введение в философию) (см.: Там же), Б. А. Тураева ${ }^{13}$ (курс истории древнего Востока). Д. В. Айналову Радлов сдал экзамен по

9 ОР РНБ. Ф. 1393. Ед. хр. 1100. Л. 22-22 об. Дата на л. 23 об. Фаддей Францевич Зелинский (1859-1944, в эмиграции) - доктор греческой словесности, профессор по кафедре классической филологии.

10 См.: Д. 56066. Л. 17 об. - 18.

11 Иван Александрович Бодуэн-де-Куртенэ (1845-1929, в эмиграции) - доктор сравнительного языковедения, заслуженный ординарный профессор (вне штата с 1.07.1905) по кафедре сравнительного языковедения и санскритского языка, см.: Отчет 1914: 10, 3-я паг. С 1918 профессор Варшавского университета.

12 Николай Онуфриевич Лосский (1870-1965, в эмиграции) - доктор философии, приват-доцент по кафедре философии, см.: Отчет 1914: 18, 3-я паг.

13 См.: Д. 56066. Л. 21. Борис Александрович Тураев (1868-1920) - историк, египтолог. Член АН (1918). 
истории искусств ${ }^{14}$, в просеминариях С. А. Жебелёва занимался Аристофаном и греческой стилистикой ${ }^{15}$, у М. И. Ростовцева выдержал экзамен по истории Рима ${ }^{16}$, у А. И. Малеина получил зачет в просеминарии по Лукрецию и латинской стилистике $\mathrm{e}^{17}$.

На лекции к Айналову записывался и Мандельштам (См.: Сальман 2010: 456, 463, 465, 466), а Лосскому, Бодуэну-де-Куртенэ и Малеину он сдавал экзамены, учась на романо-германском отделении историко-филологического факультета (подробнее см.: Там же). Осенью 1915 Радлов и Мандельштам записались на лекции к одним и тем же преподавателям: к Ф. А. Брауну на «Введение в германскую филологию» ${ }^{18}$, к Г. Ф. Церетели на занятия по Еврипиду ${ }^{19}$, к Зелинскому на историю римской литературы ${ }^{20}$.

14 См.: Д. 56066. Л. 16 об. - 17. Дмитрий Власьевич Айналов (1862-1939) - доктор теории и истории искусств, ординарный профессор, см.: Отчет 1914: 4, 3-я паг. Членкорр. АН (1914).

15 См.: Д. 56066. Л. 17 об. - 18. Сергей Александрович Жебелёв (1867-1941) - доктор греческой словесности, ординарный профессор по кафедре классической филологии, см.: Отчет 1914: 5, 3-я паг.

16 См.: Д. 56066. Л. 16 об. - 17. Михаил Иванович Ростовцев (1870-1952) - ученыйантиковед, ученик Ф. Ф. Зелинского. В 1918 эмигрировал в Англию, затем в США, где был профессором Йельского университета.

17 См.: Д. 56066. Л. 17 об. - 18. Александр Иустинович Малеин (1869-1938) - доктор римской словесности, приват-доцент по кафедре классической филологии, см.: Отчет 1914: 19, 3-я паг. Чл.-корр. АН (1916). С 1924 по 1931 работал в БАН.

18 См.: Д. 56066. Л. 23 об.; Сальман 2010: 467. Федор Александрович Браун (18621942, в эмиграции) - германист, декан историко-филологического факультета с 21 января 1912, исполняющий должность ординарного профессора по кафедре романогерманской филологии, см.: Отчет 1914: 3, 3-я паг. В 1920 он уехал из России, в 1922 1932 преподавал в Лейпцигском университете.

19 См.: Д. 56066. Л. 23 об.; Сальман 2010: 467. Григорий Филимонович Церетели (1870-1938) - профессор Петроградского университета по кафедре классической филологии с 6 октября 1914, см.: Отчет 1915: 98. 2 февраля 1914 защитил докторскую диссертацию «Новые комедии Менандра», см.: Протоколы 1916: 6, вышедшую отдельным изданием, на которое Радлов написал рецензию, см.: Радлов 1914b: 88-89. Член-корр. АН (1917). Арестовывался в 1918, в 1919 и в 1931. Профессор Тбилисского университета, он был в конце 1937 «публично объявлен Берией в числе реакционных и уже уничтоженных профессоров» (Перченок 1995: 208), арестован 24 мая 1938 и убит. По другим сведениям, умер на этапе осенью 1939, см.: Васильков, Сорокина 2003: 403 404. Мандельштам пытался 29 апреля 1916 сдать Церетели экзамен по истории древнегреческой литературы, но провалился на нем, подробнее см.: Сальман 2016: 143-144.

20 См.: Д. 56066. Л. 23 об.; Сальман 2010: 467. 
Знакомство Радлова и Мандельштама состоялось не позднее 23 ноября 1912, когда оба студента, входившие в состав группы из десяти человек, учившихся на историко-филологическом факультете, подписали прошение декану. В нем они сообщали, что хотят основать «Кружок для изучения поэзии», и приложили к прошению проект устава для кружка (подробнее см.: Сальман 2013: 167-172).

Впрочем, познакомиться они могли и раньше, например, в Обществе ревнителей художественного слова («Академии») при журнале «Аполлон», в котором впервые напечатался Мандельштам (см.: Мандельштам 1910: 5-7, 2-я паг.). В этом Обществе Радлов 22 апреля 1911 первый раз публично выступил с чтением своих стихов (см.: Тименчик 1991: 167) ${ }^{21}$.

Как образчик его поэзии приведем стихотворение 1913 из альбома А. А. Ахматовой:

Ты вошла молчаливой, гибкой.

Пред тобой я стоял немой.

Но с привычной своей улыбкой

Ты сказала: и этот мой.

И забыла. А я заметил.

Не поверил, но промолчал.

Отчего же был день так светел,

А закат особенно ал?

Может быть, ты много играешь,

Может быть, ты была права.

Ты недаром все клятвы знаешь,

Все загадочные слова.

Может быть, уж твоим и стал я,

Все иное ничто и тлен,

Но врагов бессильных, слыхал я,

Не уводят даже и в плен.

(цит. по: Тименчик 1991: 166)

21 В тот же день и Ахматова «впервые публично читала свои стихи в “Академии"» (Черных 2008: 64). 
Три переведенных Радловым стихотворения из Стефана Георге 22 были опубликованы в подборке переводов в «Аполлоне» весной 1911 (см.: Георге 1911: 41-42)23, а вскоре начинающий поэт увлекся театром. Спустя почти двадцать лет он вспоминал: «Осенью 1911 г. я впервые увидел, что такое театр и “как это делается". Было это в “Старинном театре”, куда меня позвали как стихотворца сочинять прологи для испанских спектаклей. <..> Кажется впервые я, избегавший ходить в театры, почувствовал тогда тот на всю жизнь отравляющий вкус и запах сокрушительного театрального успеха» (Казароза 1930: 61, 62) ${ }^{24}$.

Организаторами Старинного театра были Н. Н. Евреинов ${ }^{25}$, Н. В. Дризен ${ }^{26}$. Н. И. Бутковская ${ }^{27}$ и К. М. Миклашевский ${ }^{28}$. Вот как писал современник об этих постановках: «Спектакли “Старинного театра" начались 18 ноября в помещении “Соляного Городка" 29 Программа первого вечера состояла из трагедии "Фуэнте Овехуна"

22 Стефан Георге (1868-1933) - немецкий поэт-символист.

23 См. републикацию этих переводов: Георге 2009: 322-324.

24 Д. И. Золотницкий ошибочно относит постановки испанских пьес Старинным театром к 1913, см.: Золотницкий 1999: 12. Та же ошибка у В. Е. Кельнера, см.: Кельнер 2006: 95. Первая репетиция прошла 15 сентября 1911, см.: Испанский театр XVI-XVII вв. [1912?]: 7.

25 Николай Николаевич Евреинов (1879-1953, в эмиграции) - драматург, режиссер.

26 Николай Васильевич Дризен (Остен-Дризен; 1868-1935, в эмиграции) - театральный деятель, историк театра, мемуарист. Служил в драматической цензуре, редактировал «Ежегодник императорских театров».

27 Наталья Ильинична Бутковская (1878-1948, в эмиграции) - режиссер, издательница.

28 Константин Михайлович Миклашевский (1886-1944, в эмиграции) - актер и режиссер, автор книг об искусстве, см.: Миклашевский 1914-1917; Миклашевский 1924. С 1920 он читал лекции на театральном отделении Института истории искусств о театре эпохи Возрождения и о Commedia dell'arte, см.: Янгиров 1996: 409. Мандельштам был знаком с Миклашевским не позднее, чем с 1913. Поэт Б. К. Лившиц вспоминал, что встречал Мандельштама и Миклашевского в гостях у супругов Чудовских, см.: Лившиц 1989: 520-521. Жена Миклашевского писала, что перед их отъездом в Париж в 1924 Миклашевский «встретил на улице Осипа Мандельштама с женой. Они устраивались на новой квартире, у них не было никакой обстановки. Он привел их к нам и предложил взять, что им подходит. Они взяли разные вещи, особенно их привлек умывальник серого мрамора и большой фаянсовый таз в цветах» (Миклашевская, Катерли 2007: 182). Подробнее о нем см.: Чжиен 2000: 113-150; Миклашевская 2007; Янгиров 1996: 404-431. О Чудовских см. прим. 35 и прим. 91.

29 Набережная Фонтанки, дом 10. 
Лопе де Вега ${ }^{30}$. Режиссером спектакля был Н. Н. Евреинов <..>. Весь спектакль был построен, как представление в народном театре под открытым небом. <..> Второй вечер состоялся 28-го ноября, в него вошли “Благочестивая Марта" Тирсо де Молина (режиссер Миклашевский, художник Шервашидзе $\left.{ }^{31}\right)$ и первое действие “Великого герцога московского” Лопе де Вега ${ }^{32}$ (режиссер Н. И. Бутковская, художник Калмаков ${ }^{33}$ ). “Благочестивая Марта” шла как представление бродячей труппы на дворе народного трактира, а “Герцог московский” как придворный спектакль при дворе Филиппа IV. Также в виде дворцового спектакля было поставлено 6-го декабря “Чистилище св. Патрика" Кальдерона <...> (Волков 1929, 2: 222) ${ }^{34}$. Некоторые подробности об участии Радлова в постановках становятся известны из его писем к сестре. В письме от 15 ноября 1911 он сообщал:

Милая Наташенька, пишу тебе после маленького моего триумфа. А до него я был так занят и (сознаюсь потихоньку) так взволнован и заинтересован исходом дела, что не мог ничего написать. $<\ldots>$ по предложению Чудовского ${ }^{35}$ я написал Loa («хвалу») - пролог для

\footnotetext{
30 «В одном из антрактов “Фуэнте Овехуна” шли “Два болтуна" Сервантеса», - вспоминал актер А. А. Мгебров (Мгебров 1932: 54). Авторство Сервантеса под вопросом.

31 Александр Константинович Шервашидзе-Чачба (1867-1968, в эмиграции) театральный художник, был секундантом М. А. Волошина на его дуэли с Н. С. Гумилевым (1909).

32 В оригинале - El Gran Duque de Moscovia y emperador perseguido. См. также прим. 36.

33 Николай Константинович Калмаков (1872-1955, в эмиграции) - театральный художник. См. о нем: Струтинская 2004: 426-471. Опубликованы его письма к Ан. Н. Чеботаревской, см.: Струтинская 2009: 302-311.

34 О Старинном театре см.: Старк 1911; Старк 1922; Испанский театр XVI-XVII вв. [1912?]; письма Н. Н. Евреинова Н. В. Дризену и републикованную статью последнего: Лисакова 2010: 76-89.

35 Валериан Адольфович Чудовский (1882 - 4 ноября 1937, расстрелян, см.: [http://lists. memo.ru/index24.htm]) - литературный критик, секретарь журнала «Аполлон». Первый муж художницы А. М. Зельмановой, см. прим. 91. В 1904 окончил Александровский лицей, в 1910-1925 - сотрудник Публичной библиотеки. В 1925-1930 был в ссылке в Нижнем Тагиле, где служил библиотекарем Тагильского краеведческого музея, в 1930-1935 работал в ленинградском Институте механизации социалистического земледелия, арестован 7 марта 1935 и 9 марта приговорен ОСО к 5 годам ссылки, сослан в Уфу, в последний раз арестован 25 августа 1937, см.: о нем: Сотрудники РНБ
} 
одной пьесы Старинного театра - «Димитрия» (русского) Лопе де Веги ${ }^{36}$. Вчера отнес его на суд Н. И. Бутковской - она, а не Евреинов ставит эту вещь - и за немногими изменениями (я не совсем точно знал ее требования) принята с милою благодарностью, после прочтения некоторыми актерами и другими заинтересованными лицами. <...> Эти дни хожу на репетиции, отчасти надо, отчасти забавно, буду на генеральной первой вещи (мой пролог идет 25-го в первый раз). Евреинов как будто недурной режиссер, но орет и < 1 слово нрзб.> смертельно! Однако актеры вымуштрованы и послушны на редкость. Не только его, но и Бутковскую слушаются почти беспрекословно. Платы я за свою работу не взял и не хочу брать <...> Впрочем<,> стараюсь так устроить, чтобы остальная работа не страдала - уроки даю, в университет хожу, но конечно домашняя работа несколько поотстала $<\ldots>^{37}$.

Ей же - 29 ноября 1911:

$<\ldots>$ Я благодарен Валериану ${ }^{38}$ за ту историю со Стар $<$ инным> театром. <...> Но конечно большого значения своему выступлению не придаю - это был пустяк, посмотрим, удастся ли мое Loa к Патрику Кальдерона, - это гораздо серьезнее и ответственнее.

Вчера была премьера «Великого Князя» - ради полного хвастовства посылаю программу. По-видимому<,> успешно прошел и

1995-2003, 1: 569-570 (здесь указана неверная дата его гибели). Радлов познакомился с ним еще школьником, не позднее лета 1909, см., напр., письмо Чудовского к Радлову от 1 августа 1909 (дата почтового штемпеля): ОР РНБ. Ф. 625. Ед. хр. 521. Л. 7 об. и сл. По всей вероятности, благодаря Чудовскому Радлов свел знакомство с М. А. Кузминым и бывал у него, см. запись в дневнике последнего от 26 марта 1911: «<...> Радлов, за которым, по-моему, ухаживает Чудовский» (Кузмин 2005: 268). Чудовский был верным поклонником А. Д. Радловой, которая посвящала ему стихи, в частности, «Ты будешь мне Архистратигом сниться <...> (Радлова 1918: 40), подробнее см.: Тименчик 2008: 464-466; 501-504. На это стихотворение откликнулся ироничным стихотворным наброском Мандельштам: «Архистратиг вошел в иконостас, / В ночной тиши запахло Валерьяном» (Мандельштам 2009-2011, 1: 358). По мнению Е. Л. Куранды, знакомство Радлова с Чудовским состоялось в шахматном клубе, см.: Куранда 2015: 264.

36 В программке к спектаклю по пьесе Лопе де Вега «Великий князь Московский и гонимый император» сказано: “"Loa” [интермедии] по старинным образцам составил Сергей Радлов» (Струтинская 2004: 460).

37 ОР РНБ. Ф. 1393. Ед. хр. 1100. Л. 29. Л. 29 об. Л. 30.

38 В. А. Чудовскому. 
весь спектакль вообще и «Loa» в частности - после нее немного поаплодировали. $<\ldots . .>^{39}$.

«Великий князь Московский» прошел 27 раз, он оставался в репертуаре до закрытия театра в феврале 1912 (см.: Струтинская 2004: 470).

В фонде Радлова в ОР РНБ хранится несколько стихотворений, озаглавленных автором как «Вставные номера к “Благочестивой Марте”». Приведем Loa и первый куплет из песенки Хитаны к этому спектаклю.

Loa:

Эй, красавицы, красотки,

Жены, дочки, сестры, тетки,

Бросьте кухню, прялки, четки,

Торопитесь все сюда!

Если милый вас не ценит,

Если юность вам изменит,

Мы поможем; не беда!

Я пришел с моим товаром,

Научу вас разным чарам;

Отдаю почти задаром

Вот, волшебная вода,

Чтоб затмить соперниц взоры,

Чтоб вернуть, мои сеньоры,

Пролетевшие года.

Есть здесь мази, склянки, банки,

Чудотворные приманки,

O, прекрасные испанки,

Торопитесь все сюда!

Красоты одной ведь мало,

Надо<,> чтобы все прельщало,

Чтоб искусство чаровало

И природе помогало.

39 ОР РНБ. Ф. 1393. Ед. хр. 1100. Л. 25. Л. 25 об. 
Здесь у нас разнообразны

Все секреты, все соблазны,

И от самой малой дозы

Вам удастся сохранить

Губки-вишни, щечки-розы,

Зубы - перлов ценных нить.

Песенка Хитаны (первый куплет):

Приходи, когда стемнеет;

Докажу, что сердце млеет,

Я прижмусь горячим телом,

Станет страсть моим уделом.

Как сладки мои надежды,

Разорвешь на мне одежды,

А убыток возместишь,

Если поцелуй мне подаришь... ${ }^{40}$.

Актриса О. Н. Высотская вспоминала, что в спектакле «Фуэнте Овехуна» «среди бродячих артистов в роли народного поэта выступал Сергей Эрнестович Радлов. В то время (1911 год) Радлов был очень молод, выглядел совсем мальчиком. Со мной он любил говорить о поэзии, это он мне принес книгу стихов Гумилева “Жемчуга”» (Высотская 1994: 85).

В письме к сестре от 6 января 1912 Радлов подводил итог своему общению с театром:

$<\ldots>$ Старинный Театр дал мне много больше, чем несколько новых знакомств и возможность быть в так назыв<аемой> «Бродячей Собачке» <sic! - M. C.> - курьезном учреждении Бориса Пронина $<\ldots .>$. Кончает свое существование Стар $<$ инный $>$ Т $<$ еатр $>$ грустно - не в материальном отношении - сборы великолепные, а в том, что Евреинов с бар<оном> Дризеном окончательно и навсегда

40 ОР РНБ. Ф. 625. Ед. хр. 297. Л. 1. Л. 2. Весной 1923 Радлов сам поставил «Благочестивую Марту» Тирсо де Молина со своими студентами Института сценических искусств, см.: Золотницкий 1999: 50. 
поссорились <...>. Вообще количество ссор прямо ужасающее, мне удалось убедиться в том<,> что я всегда предполагал: ни одно дело не идет со столькими трениями, как театральное ${ }^{41}$.

Можно предположить, что Мандельштам видел постановки Старинного театра, во всяком случае, в заметке 1926 «Березіль», вспоминая о киевском спектакле 1919 «Фуэнте Овехуна», созданном К. А. Марджановым $^{42}$, он писал, что «этот спектакль - по прямой линии от “старинного театра” барона Дризена!» (Мандельштам 2011, 3: 218).

На романо-германском отделении университета, куда Мандельштам поступил осенью 1911, он записался к испанисту профессору Д. К. Петрову ${ }^{43}$, чья магистерская диссертация была посвящена Лопе де Вега, а докторская - истории старой испанской комедии. Мандельштам выбрал лекционный курс «Завоевание Испании арабами (история и легенда по арабским и испанским источникам)» и просеминарские занятия провансальским языком ${ }^{44}$. Нет уверенности, что он посещал выбранные курсы, так как в его матрикуле нет штампов об уплате за лекции первого семестра. На те же предметы он записался и в весенний семестр 1912 (подробнее см.: Сальман 2010: 456).

${ }_{41}$ ОР РНБ. Ф. 1393. Ед. хр. 1100. Л. 31 об. Л. 32-32 об. Дата стоит на л. 34 об.

42 Константин Александрович Марджанов (Котэ Марджанишвили; 1872-1933) режиссер, сотрудничал с МХТ, основатель Свободного театра (1913-1914). С 1922 работал в Грузии. В оформлении киевского спектакля «Фуэнте Овехуна» принимала участие Н. Я. Мандельштам, см.: Мандельштам Н. 1990: 19. В том же 1919 Марджанов поставил в Киеве фарс Миклашевского «Четыре сердцееда», см.: Золотницкий 1999: 25. 43 Дмитрий Константинович Петров (1872-1925) - доктор истории западноевропейских литератур, ординарный профессор с 18 января 1914, см.: Отчет 1915: 99. Секретарь историко-филологического факультета с 13 октября 1911, см.: Отчет 1914: 3, 3-я паг. В 1911 издал сборник стихов «Элегии и песни» (1889-1911), поэтику которого современный исследователь назвал «затхлой» для того времени, см.: Тименчик 2016: 603. «С головы до пят он был предан науке; эрудит из него вышел изумительный, преподаватель прекрасный, - хотя он и не оставил после себя ни одного труда крупного научного значения» (Пяст 1997: 114). Послужил прототипом профессора Ершова, персонажа из романа «с ключом» В. А. Каверина «Скандалист, или Вечера на Васильевском острове», см.: Чудакова, Тоддес 1981: 181.

${ }_{44}$ См.: ЦГИА СПб. Ф. 14. Оп. 3. Д. 59170. Л. 15 об.; Обозрения 1911: 23. Для занятий рекомендовалось, в частности, пособие Dozy 1881. 
В следующем 1912-1913 учебном году Петров вместо провансальского языка вел просеминарий по староиспанскому языку. Пособием на занятиях служила хроника Альфонса X Мудрого, студентам рекомендовали также грамматику Менендеса Пидаля (см.: Обозрение 1912: 23) ${ }^{45}$.

Записи в просеминарий по староиспанскому языку в матрикуле Мандельштама нет. Тем не менее нельзя исключить, что поэт все же его посещал, так как 1 мая 1913 он получил у Петрова зачет по этому предмету (см.: Сальман 2010: 459). И он был не одинок. Возможно, что именно из-за спектаклей Старинного театра, пробудивших интерес к испанской драматургии и испанскому языку, в марте-мае 1913 несколько членов Романо-германского кружка $^{46}$ (руководителем которого был тот же профессор Петров) - Н. С. Гумилев, М. А. Жирмунский ${ }^{47}$, К.-В. К. Заводзин-

45 См.: Alfonso X el Sabio 1906 и Menéndez Pidal 1905 (Шифр РНБ: 7.82.3.23. На титульном листе стоит автограф владельца «Кржевский», на обороте титульного листа находится штамп: «Дар проф. Кржевского Бориса Аполлоновича. 1887-1954 гг.»). Борис Аполлонович Кржевский (12 сентября 1887-1954; дату рождения приводим по: ЦГИА СПб. Ф. 14. Оп. 3. Д. 53306. Л. 17, в КЛЭ указана дата 25 сентября, вместо 24 сентября по новому стилю) - испанист, переводчик. В 1910 получил выпускное свидетельство Петербургского университета по романо-германскому отделению, участник романогерманского кружка (см. прим. 46).

46 Романо-германский кружок (РГК) - студенческое научное общество, устав которого был принят на заседании Совета университета 23 ноября 1909, см.: Протоколы 1910: 137,139 , а первое заседание состоялось в декабре 1909. По уставу, целью кружка было «общение на почве занятий историей, литературой и искусством германороманского мира» (Протоколы 1910: 162). На собраниях читались рефераты, иногда члены кружка выступали со своими собственными произведениями, см.: Отчет 1911: 301. На заседания в качестве гостей допускались преподаватели, выпускники романогерманского отделения, студенты-филологи других отделений и курсистки Высших женских (Бестужевских) курсов. Средства кружка складывались из членских взносов, собирался он нерегулярно. Подробнее см.: Азадовский, Тименчик 1988: 182-184; то же: Тименчик 2017: 300-301; Мочульский 1999: 123-124 (комментарий А. В. Лаврова); Сальман 2010: 459-461.

47 Мирон Аркадьевич (Ааронович) Жирмунский (31 мая 1890-1974, в эмиграции. Дату рождения приводим по Curriculum vitae, написанному в конце февраля 1916, см.: ЦГИА СПб. Ф. 14. Оп. 1. Д. 11258. Л. 4. Копия) - литературовед, искусствовед. Двоюродный брат В. М. Жирмунского, он в 1908 окончил с золотой медалью 10-ю петербургскую гимназию, в 1913 - университет с дипломом первой степени. В следующем году занимался в Париже романской филологией, «а также философией 


\begin{abstract}
ский ${ }^{48}$, Г. Л. Лозинский ${ }^{49}$, К. В. Мочульский ${ }^{50}$ и Б. Г. Тереня ${ }^{51}-$ дружно сдавали Петрову староиспанский язык, притом что это был совершенно необязательный зачет ${ }^{52}$ ! Так, Мочульский годом ранее, в 1912, уже получил у профессора зачет в семинарии по
\end{abstract}

у Н. Bergson'a» (Там же). В январе 1916 «был допущен Историко-Филологическим факультетом к чтению пробных лекций» (Там же). После революции преподавал в университете, затем в пединституте им. А. И. Герцена, от которого в августе 1924 получил командировку «за границу сроком на 3 1 $\frac{1}{2}$ месяца для научных работ в области романской филологии и для печатания исследования по изучению поэтических форм в Италии XVI в. <..>» (Там же. Л. 34). Жил во Франции, затем в Португалии.

48 Карл-Виктор Казимирович Заводзинский (20 мая 1890-1949) - польский литературный критик. Сын архитектора, см.: ЦГИА СПб. Ф. 14. Оп. 3. Д. 52994. Л. 43. Копия. Учился на романо-германском отделении историко-филологического факультета Петербургского университета в 1908-1913, см.: Там же. Л. 24, зачетное сочинение писал о Жаке Казоте, см.: Там же. Л. 29. Впоследствии жил в Польше. В интервью 1935 вспоминал о своих студенческих годах: «<... моими университетскими товарищами были Жирмунский (на протяжении всего времени учебы), а в течение более коротких периодов - Гумилев, Мандельштам и Шкловский» (Мицнер 2015: 52). Шкловский Владимир Борисович (1889-1937, расстрелян) окончил романо-германское отделение в 1910. О котором из кузенов Жирмунских идет речь, сказать определенно нельзя.

49 Григорий Леонидович Лозинский (7 февраля 1889-1942, в эмиграции ) - младший брат М. Л. Лозинского, переводчик, критик. Окончив петербургскую 1-ю гимназию, см.: ЦГИА СПб. Ф. 14. Оп. 3. Д. 61116. Л. 33, учился на юридическом факультете в 1906-1910, см.: Там же. В 1912 поступил на романо-германское отделение историкофилологического факультета, которое закончил в 1915, см.: Там же. Л. 10. О его жизни после революции см.: Тименчик 2008: 65-68 и по указателю; Толстая 2004: 56-59.

50 Константин Васильевич Мочульский (1892-1948, в эмиграции) - критик, литературовед, автор мемуаров о Мандельштаме, Е. Ю. Кузьминой-Караваевой (матери Марии). Подробнее см. во вступительной статье А. В. Лаврова: Мочульский 1999.

51 Борис Григорьевич Тереня (22 апреля 1888 - ?) - сын судебного пристава Григория Пантелеймоновича Терени, см.: ЦГИА СПб. Ф. 14. Оп. 3. Д. 54134. Л. 9. Копия. Л. 12. Копия. Учился в Ченстоховской, в Варшавской и один год в 1-й петербургской гимназии, после окончания которой в 1908 был зачислен на юридический факультет Петербургского университета. Той же осенью, уйдя из университета, поступил в Институт инженеров путей сообщения, см.: Там же. Л. 5. Л. 6. Л. 31. В 1909 перешел на романо-германское отделение историко-филологического факультета Петербургского университета, которое закончил в 1915, см.: Там же. Л. 37. В 1913 прочел в РГК доклад «Мадам де Сталь, ее жизнь и произведения», см.: Отчет 1914: 384 . В 1914 выступил с докладом «Мадам де Сталь и ее книга “О Германии”», см.: Отчет 1915: 235.

52 Студент-романист должен был получить зачет по четырем просеминариям: по одному из романских языков; по одной из романских литератур; по одному из германских языков; по одному из предметов факультета по выбору студента, см.: Сальман 2010: 456. 
провансальскому языку ${ }^{53}$, а Заводзинский сдавал в качестве обязательного предмета старофранцузский язык ${ }^{54}$.

Некоторые члены РГК принимали непосредственное участие в постановках Старинного театра. Процитируем письмо С. М. Городецкого В. А. Пясту (который покинул университет в 1910, но исправно посещал кружок) от 29 апреля 1911:

Бар<он> Николай Васильевич Дризен, желая воспользоваться для «Старинного Театра» Вашими, Владимир Алексеевич, познаниями в области испанского языка и литературы, просит меня передать Вам, что он ждет Вас к себе в драматическую цензуру (Театральн<ая> улица или площадь) в один из ближайших дней, после 4 часов дня. С. Городецкий ${ }^{55}$.

По-видимому, отголоском все тех же спектаклей стало торжественное заседание в память 350-летия со дня рождения Лопе де Вега, которое 28 ноября 1912 устроили в университете романо-германисты (подробнее см.: Мочульский 1999: 153-154 и комментарий А. В. Лаврова: 155).

Полученные знания в староиспанском пригодились Мандельштаму спустя четверть века. Его вдова вспоминала: «Испанцев брал в 36-37 г. в Вор<онежской> библ<иотеке>. Там была многотомная антология кастильцев. В ней заблудился. Сида прочел <...> (Мандельштам Н. 2017: 20) ${ }^{56}$.

Вернемся к Радлову. В конце 1913 он познакомился с Анной Дмитриевной Дармолатовой ${ }^{57}$. В марте 1914 решился вопрос о браке ${ }^{58}$, но 8 апреля невеста уехала на два месяца за границу. Радлов записывал для себя:

\footnotetext{
53 См.: ЦГИА СПб. Ф. 14. Оп. 3. Д. 56714. Л. 38 об. - 39.

54 См.: Там же. Д. 52994. Л. 24.

55 ОР РНБ Ф. 248. Ед. хр. 121. Л. 10.

56 О занятиях Мандельштама современным испанским языком в Воронеже см.: Мандельштам Н. 1989: 202.

57 Анна Дмитриевна Радлова (урожд. Дармолатова; 1891-1949, в лагере) - поэтесса, переводчица.

58 См.: ОР РНБ. Ф. 625. Ед. хр. 2.
} 
Губы еще помнят ее губы<,> какая невероятная мука. Я начинаю понимать, что от горя сходят с ума. Господи, дай поскорее пройти этим ужасным дням ${ }^{59}$.

Прошение ректору о разрешении вступить в брак «с дочерью коммерции советника» было подано Радловым 26 июня $1914^{60}$. Венчание состоялось 15 августа 1914 в Павловске, в Мариинской придворной церкви ${ }^{61}$. Спустя год у супругов родился сын Дмитрий ${ }^{62}$.

С осени 1913 Радлов посещал Студию В. Э. Мейерхольда на Бородинской улице, где заинтересовался искусством пантомимы. По воспоминаниям А. Л. Грипича, радловская труппа «отличалась романтизмом своих сюжетов, мягкостью, изяществом и даже манерностью исполнения» ${ }^{63}$ (Панфилова, Фельдман 2000b: 375). Впрочем, художник В. В. Дмитриев ${ }^{64}$ утверждал в беседе, что в Студии «многие из тех, кто ее посещали, не принимали практического участия в занятиях, а просто ходили туда и смотрели на то, что делалось. Вл. Н. Соловьев ${ }^{65}$ бывал там часто и занимался, по преимуществу, разговорами. То же делали В. В. Дмитриев, С. Э. Радлов (писавший тогда стихи). Миклашевский рассказывал o commedia dell'arte» ${ }^{66}$ (Чушкин 2004: 360) ${ }^{67}$.

59 Там же.

60 См.: Д. 56066. Л. 40.

61 См.: Д. 56066. Л. 43 об. Воспользуемся случаем, чтобы исправить ошибку исследовательницы, которая сообщает, что свадьба Радлова и А. Д. Дармолатовой состоялась 20 марта 1914, см.: Куранда 2016: 93.

62 Дмитрий Сергеевич Радлов (1915-1969) - актер, режиссер. См. также прим. 145.

63 Алексей Львович Грипич (1891-1983) - режиссер, мемуарист. Известна дарственная надпись Мандельштама ему на «Камне»: «Алексею Львовичу Грипичу с добрым чувством. Автор. 20 ноября 1913» (Парнис 1991: 201).

64 Владимир Владимирович Дмитриев (1900-1948) - театральный художник.

65 Владимир Николаевич Соловьев (псевд. Вольмар Люсциниус; 1887-1941) - режиссер, критик, постоянный сотрудник Мейерхольда в Студии на Бородинской и в журнале «Любовь к трем апельсинам».

66 O commedia dell'arte Миклашевский писал, что ее признаком являлось коллективное творчество актеров: фабула для представления либо заимствовалась из старинной комедии или новеллы, либо сочинялась (см.: Миклашевский 1914-1917: 11). Создавался «скелет театрального действа (Scenario), причем текст каждой роли почти всецело оставлялся на усмотрение актера» (Там же).

67 Запись беседы с В. В. Дмитриевым от 12 марта 1948, поэтому рассказчик и назван в цитате в третьем лице. 
Когда в 1914 Мейерхольд готовил к постановке в Тенишевском училище пьесы А. А. Блока, он выбрал Радлова на роль Гауптмана в «Незнакомке» и Голубого в «Балаганчике» (см.: Панфилова, Фельдман 2000а: 326, 328), но в конечном счете эти роли достались другим актерам. Возможно, что причина была в самом Радлове, который 26 января 1914 писал будущей жене: «И к Вашему противному реферату присоединился мой еще более противный спектакль. <..> Меня вдруг почти перестал интересовать театр» (цит. по: Сальман 2009: 295).

Спектакль прошел семь раз на сцене Тенишевского училища (с седьмого по одиннадцатое апреля 1914 (см.: Петровская, Сомина 1994: 330), его посетили и Мандельштам, и Радлов, который 10 апреля писал А. Д. Дармолатовой: «Сейчас был на Блоковских пьесах. <...> Спектакль - Бог с ним, я уже чужой для того, что там, по крайней мере, пока» (Блок 1982: 432).

Покинув Студию в конце марта 1914 (см.: Панфилова, Фельдман 2000b: 379), Радлов, однако, поддерживал отношения с Мейерхольдом, который оставил дарственную надпись Радлову «на титульном листе книги: Бонди Ю., Мейерхольд Вс., Вл. Соловьев. Огонь: 8 картин и Апофеоз: Стихи. - Пг., 1915» (Кельнер, Новикова 2005: 613) ${ }^{68}$; процитируем ее: «Сергею Эрнестовичу Радлову. // Тому, кто, выходя к актерам на их сценическую площадку, умеет найти для себя волшебную палочку, для себя и для них, ему подчиненных актеров. // Вс. Мейерхольд. // 26 окт<ября> 1915. Петроград» (Там же).

В мейерхольдовском журнале Радлов опубликовал и перевод комедии Плавта «Близнецы» (см.: Плавт 1915: 17-116). На отдельное издание пьесы, вышедшее в 1916, написал рецензию Чудовский:

От стихотворных переводов мы требуем «размера подлинника», требование это (очень спорное!) как будто прочно стоит на первоосновах нашей формальной культуры («соблюсти стиль»).

68 Юрий Михайлович Бонди (1889-1926) - художник, режиссер, один из руководителей Студии на Бородинской. Он был художником блоковских спектаклей, прошедших в Тенишевском училище. 
Тем любопытнее, что мы лишь теперь впервые увидели в печати перевод большого античного драматического произведения с последовательным соблюдением всех размеров подлинника. Для Плавтовых «Менехмов» Сергею Радлову пришлось их дать не менее четырнадцат и <..>. Но главное значение этого перевода с формальной стороны, конечно, в разработке ямбового триметра, этого господствующего стиха в античном театре. Можно очень многое сказать и за и против его перенесения в наше стихосложение. <...> До сих пор лучшие мастера Ф. Ф. Зелинский и И. Анненский заменяли его русским пятистопным ямбом (менее пригоден ямб шестистопный, примененный проф. Церетели к Менандру). <..> Перевод Радлова сделан с таким вниманием к стилю и формальному воспроизведению, что даже каламбуры, аллитерации, внутренние рифмы, ассонансы и т. п. соблюдены с достойным удивления тщанием (Чудовский 1916: 87, 88, разрядка автора).

В этом же номере «Аполлона» Litotes - Н. В. Недоброво ${ }^{69}$ - поместил сообщение о состоявшемся 5 апреля 1916 заседании в Обществе ревнителей художественного слова, которое вел Зелинский. Почти все ораторы - среди них были С. К. Маковский, Б. В. Томашевский, Чудовский и сам Недоброво - «решительно ополчились против античных метров, доказывая стеснительность их, эстетическую неоправданность и даже принципиальную невозможность в условиях русского языка. <..> Единственным сторонником античной метрики, изложившим свои доводы, оказался Сергей Радлов <...> (Litotes 1916: 86).

В артистических кабаре «Бродячая собака» и «Привал комедиантов» Радлов, по всей вероятности, также встречался с Мандельштамом (см.: Шруба 2004: 173), виделись они и на заседаниях «Цеха поэтов», куда Радлов был кооптирован в феврале 1913 (см.: Тименчик 2008: 484). Он, как и А. Д. Радлова, был членом и второго «Цеха поэтов» (см.: Тименчик 2016: 280), о котором Ин. А. Оксенов 69 Николай Владимирович Недоброво (1882-1919) - поэт, критик. Расшифровку
псевдонима приводим по: Дмитриев 2009: 155. 
вспоминал: «<..> собирался цех довольно редко, приблизительно раз в месяц, меняя место собрания. Последние происходили у Г. Адамовича, Г. Иванова (чаще всего), были собрания у <..> С. Радлова <...> (Книги и рукописи в собрании М. С. Лесмана 1989: 370).

О посещении поэтом дома Радловых становится известно из неопубликованного письма Н. Э. Казанской от 18 ноября 1915, в котором она пишет о семье брата:

Устроили они раз вечер с поэтами, с Гумилевым, Мандельштамом, Чудовским и др. Было очень мило, если бы не Мандельштамовские стихи. Сережа написал комедию $<. . .>^{70}$.

Свидетельством их тесного общения в это время служит мандельштамовский инскрипт Радлову на авантитуле второго издания «Камня»: «Дорогому Сергею Эрнестовичу // дружески // Осип Мандельштам // 28 дек. 1915 г.» ${ }^{71}$.

Радлов не успел вовремя окончить университет (по правилам в университете можно было оставаться не более пяти лет, курс обучения был рассчитан на четыре года), и ему пришлось хлопотать о продлении срока. 21 мая 1915 министерство народного просвещения сообщило попечителю Петроградского учебного округа, что оно «разрешает студентов историко-филологического факультета ИМПЕРАТОРСКОГО Петроградского университета <...> Сергея АДОВА и Сергея $\underline{\text { БОНДЙ}}{ }^{72}$, подлежащих увольнению по

70 ОР РНБ. Ф. 1393. Ед. хр. 951. Л. 1. Факт посещения Мандельштамом Радловых в первой половине ноября 1915 не отмечен в: Мандельштам 2014 и в: Летопись 2016. Возможно, что это было одно из литературных собраний, которые устраивал Гумилев и о котором говорится с упоминанием месяцев («Между октябрем и декабрем»), но без указания даты у П. Н. Лукницкого: «Собрания устраивались в течение всей зимы <..> одно - у Радловой <...>» (Лукницкий 2010: 423).

71 Шифр РНБ 37.59.7.337а. В первой публикации инскрипта А. Г. Мецем дана ссылка на частное собрание, см.: Мандельштам 1990: 280; во второй публикации был указан верный шифр ГПБ, а сам инскрипт приведен с мелкой неточностью, см.: Парнис 1991: 202. Инскрипт был также процитирован В. Е. Кельнером без ссылки на шифр книги, см.: Кельнер 2006: 100. В нашей публикации инскрипт был описан de visu, см.: Сальман 2009: 295.

72 Сергей Михайлович Бонди (1891-1983) - литературовед, пушкинист, младший брат Ю. М. Бонди. 
ст<атье> 526, т. XI, Св<ода> Зак<онов>, изд. 1893 г., оставить в университете для окончания университетского образования. $<. . .>{ }^{73}$.

Помешавшие ему причины нам неизвестны, сестре, упрекнувшей его в том, что он живет на содержании у жены, Радлов отвечал 13 февраля 1916:

Я не оспариваю фактической истинности такого утверждения. То, что я зарабатываю, конечно, слишком мало, чтобы лишить возможности это говорить людей, которые относятся ко мне дурно. Но Тебе не следовало делать этого. Ты знаешь, что<,> решившись на женитьбу<,> я через год надеялся кончить университет. Ты знаешь, какие обстоятельства помешали окончанию и как мне было нелегко от него отказаться. Я не думаю, чтоб было великодушно задевать наболевшее место. <...> Я слишком хорошо знаю, что Ты осуждаешь меня не одна. Но Борис ${ }^{74}$, осуждая, молчит, по крайней мере, при мне. $<\ldots>^{75}$.

19 апреля 1916, имея восемь зачтенных полугодий, Радлов получил университетское выпускное свидетельство № $1258^{76}$. Жил он в это время на Васильевском острове, на 6-й линии, в доме 29, кв. $12^{77}$. 28 сентября 1916 он был оставлен при университете «по кафедре классической филологии для приготовления к профессорской и преподавательской деятельности на два года $<\ldots .>{ }^{78}$. По окончании университета Радлов преподавал (по-видимому, латынь) в Училище правоведения ${ }^{79}$.

15 декабря 1916 и 13 января 1917 в «Обществе изучения современной поэзии» при редакции журнала «Аполлон» В. М. Жирмунский прочел два доклада об эротических балладах В. Я. Брюсова из сборника «Urbi et Orbi». При обсуждении доклада 15 декабря, судя по конспекту Б. М. Эйхенбаума, выступили «В. А. Чудовский,

73 Д. 56066. Л. 4. Копия.

74 Б. В. Казанский.

75 ОР РНБ. Ф. 1393. Ед. хр. 1100. Л. 42. Л. 43. Дата на л. 43.

76 См.: Д. 56066. Л. 8.

77 См.: Там же. Л. 7.

78 ОР РНБ. Ф. 625. Ед. хр. 3. Л. 1.

79 См.: Там же. Ед. хр. 668. Л. 21. 
К. В. Мочульский, С. Э. Радлов, Мандельштам <..> В. Пяст <..>» (Тименчик 2008: 470). Эти доклады представляли собой первую главу из книги ученого «Валерий Брюсов и наследие Пушкина» (1922). Вторую главу - о «Египетских ночах» Брюсова - Жирмунский прочел летом 1917 в Алуште (см.: Жирмунский 1977: 381), где отдыхали и супруги Радловы и Мандельштам.

В Алуште добрые знакомые Мандельштама написали пьесу и сыграли спектакль, чему посвящена целая книга «Кофейня разбитых сердец».

Текст пьесы сообщила Н. В. Султанова, она же расшифровала имена персонажей ${ }^{80}$, в чем участвовала и В. Ф. Шухаева ${ }^{81}$.

80 См.: Тименчик 2008: 444. Наталья Владимировна Султанова (урожд. Шумкова; в первом браке Гвоздева; 21 марта 1895-1976, дату рождения указываем по: ЦГИА СПб. Ф. 113. Оп. 7. Д. 193. Л. 10) училась в петербургской частной гимназии М. Н. Стоюниной. Поступив в 1904 в подготовительный класс, закончила гимназию в 1912 и «получила право на золотую медаль» (Там же. Л. 4 - 4 об.). В 1913 окончила VIII дополнительный класс и была «признана Педагогическим Советом достойною звания Домашней Наставницы» (Там же. Л. 14). В 1913 поступила на историко-филологический факультет Высших женских (Бестужевских) курсов, см.: Там же. Л. 1. Бракосочетание с А. А. Гвоздевым состоялось 9 ноября 1914, см.: Там же. Л. 2 об. Копия, Л. 16. Копия. См. о ней: Мочульский 1999, passim и в комментарии А. В. Лаврова; Тименчик 2008: 472-473. О ней и ее третьем муже Л. Л. Ракове, см.: Куранда 2015: 242, 244, 245.

81 См.: Тименчик 2008: 473. Вера Федоровна Шухаева (урожд. Гвоздева; 1896-1979) художник по тканям. Окончила гимназию М. Н. Стоюниной, ее одноклассницами были Н. В. Султанова и будущая поэтесса и автор мемуаров о Блоке и Мандельштаме Е. М. Тагер (1895-1964), которая писала о Шухаевой в письме к Л. В. Шапориной 13 июля 1955: «<...> моя подруга (вдвойне подруга - по гимназии и по Колыме <...» (ОР РНБ. Ф. 1086. Ед. хр. 34. Л. 35). Вторая жена художника В. И. Шухаева (см. прим. 93), вместе с которым в 1920 бежала из Петрограда в Финляндию. Там, в пансионе Линде в Мустамяки (сейчас пос. Горьковское в Выборгском районе Ленинградской обл.), они прожили год у приютившей их Анны Федоровны Гейнц (урожд. Линде; 1885-1927), см.: Яковлева 1991: 79, 87. Сестра мандельштамовского друга юных лет математика Ф. Ф. Линде (1881-1917; см. о нем: Сальман 2017, 1:311-312), А. Ф. Гейнц, танцовщица, была участницей мейерхольдовской Студии на Жуковской в 1908-1909, см. ее воспоминания в письме к Н. Д. Волкову: Волков 1929: 40-41, играла в пантомиме А. Шницлера «Шарф Коломбины», которую Мейерхольд поставил в «Доме интермедий» в 1910 и где роли Арлекина и Пьеро исполняли художники А. Е. Яковлев и В. И. Шухаев. Последний написал сангиной и углем портрет Гейнц в костюме Коломбины, см.: Яковлева 1989 (портрет воспроизведен на обложке журнала). Гейнц принимала участие в спектаклях Старинного театра сезона 1911-1912. В Москве в 1913 играла в театре-кабаре «Летучая мышь» Н. Ф. Балиева, «где выделялась своим изяществом, грацией и темпераментным 
Исследователь пишет, что весной 1920 Радлов сообщил в печати о прошедшем в Алуште представлении: «В августе 1917 года мною был поставлен спектакль в г. Алуште на началах словесной импровизации, в котором одна из участниц, М. Ф. Гвоздева ${ }^{82}$, выступала с акробатическим номером» (Тименчик 2008: 470).

Приводимые выдержки из письма Радлова к сестре позволяют внести некоторые дополнения в историю вопроса.

22 августа 1917 Радлов писал Н. Э. Казанской из Алушты:

Милая моя Наташенька, поздравляю Тебя с днем Ангела <...> У нас же все неясно и все несколько мрачно. В лучшем случае будет так. Я уеду отсюда 1 Сентября один. Вместо меня поедет в Крым $\mathrm{M}<$ ария > Ник<олаевна > с детьми ${ }^{83}$, Нюра же на какой-нибудь месяц приедет в город. $<\ldots .>$

Нюрушка пишет стихи и очень хорошие. Я объединился с Мочульским, специалистом по италианской импровизованной комедии<,> и читаю с ним итал<ьянские > сценарии ${ }^{84}$ в обмен

исполнением» (Старк 1932: 36). Как и Радлов, занималась у Мейерхольда в Студии на Бородинской, сочинила пантомиму «Трое», см.: Панфилова, Фельдман 2000b: 374, 375. После 1921 А. Ф. Гейнц вернулась из Финляндии в Россию, жила в Москве, где ее муж служил на фабрике Гознака на административных должностях, см.: Яковлева 1991: 87. В 1926 была актрисой театра Мейерхольда. Утонула, спасая чужого ребенка, см.: Мгебров 1932: 36, комментарий Э. А. Старка. Живя в Мустамяки, Шухаев написал портрет матери А. Ф. Гейнц и Ф. Ф. Линде - Паулины Фелициановны Линде, см.: Яковлева 1991: 87. В начале 1921 семья Шухаевых уехала из Финляндии во Францию, жила в Париже, в 1934 вернулась в СССР. В. Ф. Шухаева была арестована вместе с мужем в апреле 1937. Освободились они в 1945, поселились в Тбилиси. «В 48-м арест по второму разу. Ненадолго. Через два месяца освободили. И мы остались в Тбилиси. В 53-м похуже, чем арест, высылка из Тбилиси. Несколько месяцев мы маялись и мыкались по Грузии, потом разрешили вернуться. Шухаев снова стал профессором Академии художеств. И, наконец, в 58-м пришла реабилитация» (Гвоздева М. 1998: 87).

82 Мария Федоровна Баскова (урожд. Гвоздева; 1900-1981) - младшая сестра В. Ф. Шухаевой, училась во ВХУТЕМАСе, архитектор, мемуаристка (ее воспоминания были опубликованы под девичьей фамилией).

83 Мария Николаевна Дармолатова (? - 1942), мать А. Д. Радловой и ее сестер, скульптора Сарры Дмитриевны (в замужестве Лебедевой; 1892-1967), Веры Дмитриевны (1895-1919, покончила с собой) и Надежды Дмитриевны (1895-1922). Вероятно, в Алуште находились две младшие незамужние сестры А. Д. Радловой. См. ниже письмо А. Д. Радловой, прим. 100.

84 Слово «сценарий» используется в значении, о котором писал Миклашевский, «скелет театрального действа», см. прим. 66. 
на латинскую комедию, кот<орую> я ему перевожу ${ }^{85}$. Но были и практические результаты. Мы попробовали с ним, как-то сидя со всеми на балконе, импровизировать самим в духе италианской комедии (следов<ательно><,> немного в роде Мольера ${ }^{86}$ и Шекспира по стилю). Нам понравилось<,> и в результате мы сыграли на большом благотворительном вечере целую комедию на заданную тему к большому недоумению одесситов и восторгу Магдейцев ${ }^{87}$.

Мне это дало необычайно много, ибо я почувствовал, что могу свободно и театрально говорить на сцене<,> совершенно не затрудняясь подбором слов. Очень важно мне было сделать этот опыт и для занятий в Студии, если они только состоятся при нынешних условиях.

Есть у нас и еще виды культурного времяпрепровождения. Изредка устраиваем нечто вроде научных заседаний или собеседований в составе Алекс<андр $>$ Алекс<андрович> Смирнов милейший и умный человек ${ }^{88}$, Витя Жирмунский - очень жалко, что вы не будете пользоваться обществом этого прелестного человека<,> - Мочульский, Валериан ${ }^{89}$, Серг $<$ ей $>$ Рафалович -

85 Возможно, это была комедия Плавта. В письме к В. М. Жирмунскому от 16 октября 1917 Мочульский сообщал: «Грустно было расставаться со светлым, по-осеннему сверкающим Крымом, жаль было покидать свою голубятню, где я с таким увлечением читал Плавта <...» (Мочульский 1999: 185).

86 Тремя годами ранее, в рецензии на книгу профессора Церетели, Радлов писал о нити развития, ведущей «от Мольера через испанскую и итальянскую комедию к комедии римской - Плавта и Теренция, вплоть до времени Еврипида и Аристофана» (Радлов 1914b: 88).

87 Магдейцы - обитатели дачного пансиона под Алуштой, принадлежавшего матери Елизаветы Петровны Магденко (? - 1923), первой жены А. А. Смирнова, см. прим. 88). Мать «сдавала маленькие дачи, стоящие на территории ее дачи, ученым и писателям, откуда название “профессорский уголок” (Смирнов 2011: 8, примечание Д. Малмстада). Радлов с женой, сыном, свояченицами и тещей М. Н. Дармолатовой жили в доме на Таврической улице, см.: ОР РНБ. Ф. 1393. Ед. хр. 713. Л. 13 об.

88 Александр Александрович Смирнов (1883-1962) - приват-доцент Петербургского университета, в дальнейшем филолог-медиевист, кельтолог, переводчик. Подробнее см.: Русские писатели 1989-2007, 5: 670-672. Ему посвящено стихотворение Радловой «Ангел песнопения», см.: Радлова 1918: 25. В 1920-е дома у Радловых «часто бывал $<$ А. А.> Смирнов и Н. <В.> Султанова» (Кузмин 2007: 148). См. о нем монографию: Каганович 2018.

89 В. А. Чудовский. 
плохой поэт и преглупый человек ${ }^{90}$, Анна, я и т. д. Надо сознаться<,> что здесь для летнего времени редкое собрание людей для нас близких и интересных, т<ак> ч<то > пока еще <?> мы духовно не опровинциалились, что очень возможно этой зимою в диком Петрограде.

- Вчера начала Нюрушкин портрет Зельманова ${ }^{91}$. Мне еще не показывали, Нюра говорит, что хорошо. Вообще у нас очень милые отношения с “Аннушкой”. Она<,> несомненно<,> добродушный и приятный человек, хотя и глупенькая. - Мне страшно приятно, что это уже второй портрет Нюрки за лето. $<\ldots>^{92}$.

Первый портрет Радловой лета 1917 был написан художником В. И. Шухаевым ${ }^{93}$. В письме к Казанскому, отправленном месяцем раньше, 22 июля 1917, Радлов сообщал:

Дорогой Борис, поздравляю Тебя с именинами и прошу извинить за неприличное мое молчание. Оно в значительной мере объясняется тем, что как раз в ответ на Твои летние планы занятий я мог написать Тебе очень мало содержательного и утешительного.

90 Сергей-Мари Львович Рафалович (8 августа 1875-1944, в эмиграции; дату рождения указываем по аттестату зрелости, см.: ЦГИА СПб Ф. 14. Оп. 3. Д. 30407. Л. 3) - поэт, драматург, критик. Сын купца первой гильдии Льва Анисимовича Рафаловича, см.: ЦГИА СПб Ф. 14. Оп. 3. Д. 30407. Л. 9. Копия. Учился на историко-филологическом факультете в 1893-1897, на юридическом в 1894-1897, см.: ЦГИА СПб: Д. 30407. Л. 31. Л. 38. Л. 14. Автор десятков стихотворных сборников. Подробнее см.: Русские писатели 1989-2007, 5: 264-266. Здесь датой рождения указано 4 августа, а приведенное в словаре второе отчество «Зеликович» (точнее, Зелихович) - следствие путаницы: оно относится к другому Сергею Рафаловичу, который родился в Петербурге 20 апреля 1877 , окончил Николаевскую царскосельскую гимназию и учился в Петербургском университете в 1896-1903, подробнее см.: Сальман 2010: 490.

91 Анна Михайловна Зельманова (1891-1952) - художница, в первом браке жена В. А. Чудовского, во втором Б. Белокопытова (в «Кофейне» она фигурирует как «Белла Капите»), автор портретов Мандельштама и Ахматовой. Подробнее см.: Тименчик 2008 по указателю. Зимой 1915 была на фронте в качестве сестры милосердия, см. публикацию ее писем к Н. Э. Казанской: Куранда 2016: 89-96.

92 ОР РНБ. Ф. 1393. Ед. хр. 1100. Л. 44-45. Фрагмент письма от слов «Вчера начала Нюрушкин» и до «за лето» цитировался без указания листа рукописи и с ошибкой в одном слове («Нюры» вместо верного «Нюрки»), см.: Куранда 2016: 94.

93 Василий Иванович Шухаев (1887-1973) - живописец, учился в Академии художеств вместе со старшим братом С. Э. Радлова, Н. Э. Радловым. 
Как и обыкновенно летом, я веду образ жизни чрезвычайно растительный. Купаюсь и валяюсь на берегу, играю в теннис $<\ldots>$ Все же я не могу сказать, чтобы я ровно ничего не делал. Во-первых, <2 слова нрзб.> даю уроки Лиле Переплетник ${ }^{94}$, что при здешней дороговизне не является <2 слова нрзб.> подспорьем. Во-вторых, читаю Плавта и жене Шухаева. Кроме того<,> что она мне мила, а перечитывать Плавта всегда приятно, я еще рад хоть несколько поблагодарить Шухаева за царский подарок. На 5-е Июля он подарил мне рисунок - портрет Нюры, похожий и красивый $95 .<\ldots>$ Самым туманным для нас вопросом является будущая зима. Я очень рад за вас, что вы в Перми. В Петрограде почти обеспеченный голод. Вряд ли откроются учебные заведения. Нюре придется остаться с Митькой, $6<$ ыть $>$ м<ожет $><,>$ гденибудь в Крыму. Будет ли для меня необходимо жить в Петрограде или нет, не имею понятия. <...>96.

Благодаря приведенному письму Радлова к сестре выясняется, что импровизированная «комедия на заданную тему» была сыграна «на большом благотворительном вечере». Авторов было двое: Радлов и Мочульский. Из письма Радлова становится понятным, что разыгранная импровизация (да еще и с акробатическим номером М. Ф. Гвоздевой) отнюдь не была спектаклем со сложно организованным текстом, - тем текстом «Кофейни», который был опубликован в 1997. Как пишет и один из публикаторов, «<...

94 См. упоминание о «салоне мадам Переплетник» в «Египетской марке» (Мандельштам 2010, 2: 275). Ср. в письме Мочульского к В. М. Жирмунскому от 3 июня 1917: «<..> Переплетник, Гвоздевы, Радловы, моя кузина с семьей; все это очень хорошо зимой, а летом утомительно» (Мочульский 1999: 182). По всей вероятности, имеется в виду Елизавета, жена адвоката Григория Моисеевича Переплетника (1886-1942), в 1920-е они жили в Берлине, затем в Париже. Были депортированы немцами, см.: Будницкий, Полян 2013:308 и погибли в Освенциме. См.: Гольденвейзер 2005: 388, комментарий А. Зейде; Соболев 2017: 145.

95 Портрет был испорчен или уничтожен прислугой, С. Э. Радлов сообщил об этом жене, находившейся в Ялте. Она ответила 4 января 1918: «Ужасно, ужасно, что погиб портрет. Ведь это не скрыть. Рано или поздно Вася узнает об этом, да и все узнают. Это - настоящий стыд» (ОР РНБ. Ф. 625. Ед. хр. 478. Л. 4).

96 ОР РНБ. Ф. 1393. Ед. хр. 713. Л. 13-13 об., дата на л. 13. 
В. Ф. Шухаевой помнилось, что разыграна была не "Кофейня", а другое коллективное сочинение. Кем именно и когда был зафиксирован текст "Кофейни", чем вызваны некоторые дефекты текста - В. Ф. Шухаева и Н. В. Султанова в 1970-х объяснить уже не могли» (Тименчик 2008: 470).

Возможно, что «Кофейня» писалась по следам спектакля как текст для чтения, в основу которого легли некоторые реальные факты алуштинской жизни, хотя и очень преображенные талантливыми и остроумными авторами (или автором). Достаточно сравнить сцену, в которой Радулус (Радлов) приходит к Моне Феде (Шухаевой) читать Плавта по латыни ${ }^{97}$, и рассказ о чтении Плавта в письме Радлова Казанскому. Остается надеяться, что когда-нибудь будут найдены новые материалы, из которых станет известна точная история текста «Кофейни разбитых сердец». Пока с большой долей уверенности можно сказать, что одним из ее авторов был Сергей Радлов.

29 сентября 1917 он сообщал сестре из Алушты:

Дорогая моя Наташа, сим объявляю вам с Борисом, что вы свиньи. Еще в Августе мы послали вам кучу писем и стихов. <...> У нас случилось много и очень нешуточного. Анна была больна $<\ldots>$. Пришлось решиться на немедленную операцию, которую мы осуществили здесь $<$,> в нашем же пансионе, приняв соответственные меры предосторожности. Это было 26-го, а сегодня Анна чувствует себя уже настолько хорошо, что я могу рассказывать об этом спокойно. <...> В Ялте, куда мы поехали для этого, оказались переполненными все лечебницы<,> и мы должны были вернуться, выписав оттуда доктора. <..> я был в Петрограде, очень недолго, от 9-го до 18-го Сент<ября $><,>$ т<ак $>$ к<ак $>$ получал от Анны тревожные письма<,> у нее каждый день повышалась температура. Кроме того <,> оказалось, что у нее - по-видимому<,> отчасти из-за морских купаний, - расширение сердца, настолько серьезное,

97 См.: Кофейня 1997: 46-48. 
что вся операция прошла без какого-либо наркоза. Она выдержала боль изумительно $<\ldots>^{98}$.

\section{4 ноября 1917 Радлов писал Казанскому из Алушты:}

\section{Дорогой Борис,}

Спасибо Тебе, что собрался написать мне; животворящий голос из пермского Эльдорадо радует необычайно. Так приятно думать, что есть все же близкие люди, жизнь которых не ухудшилась в этом году ${ }^{99}$. Дай Бог, чтобы это так осталось и чтобы невиданный русский позор не коснулся вас как-нибудь непосредственно.

Не могу сказать, чтобы он не коснулся нас. Не только живем мы под угрозой остаться без присылки денег, но и душевное угнетение

98 ОР РНБ. Ф. 1393. Ед. хр. 1100. Л. 46. Л. 47. Л. 47 об.

99 О ситуации в Перми в сравнении с Петроградом приведем свидетельство близкой подруги Н. Э. Казанской, М. А. Кржевской (жены Б. А. Кржевского с 1913, см.: Табункина 2015: 138), которая вспоминала в письме к Б. В. Казанскому от 10 октября 1958: «Мы с Б<орисом> А<поллоновичем> приехали в Пермь 13/X 1917 года по ст<арому> ст<илю> - там был уже снег и я, сидя в “Альпийской Розе”, среди колбас и пирожных, вкушала чай» (ОР РНБ. Ф. 1393. Ед. хр. 640. Л. 29). Марина Арсеньевна Кржевская (урожд. Филаретова; 23 июня 1886-1967?; дату рождения, год и девичью фамилию приводим по: ЦГИА СПб. Фонд 2. Опись 1. Дело 15316. Л. 2. Год рождения 1893, указанный в: Табункина 2015: 138, неверен. Год смерти см.: Хлебникова-Смирнова 1994 [https://www. sakharov-center.ru/asfcd/auth/?t=page\&num=4937]). Дочь статского советника Арсения Ивановича Филаретова, она была принята в Смольный институт (в пятый класс) в 1899 и закончила его в 1904 с серебряной медалью, см.: ЦГИА СПб. Фонд 2. Опись 1. Дело 15316. Л. 2, Л. 11, Л. 39. В Перми семьи Кржевских и Казанских тесно общалась. В середине 1920-х развелась с Кржевским и вышла замуж за экономиста Исаака Иосифовича Гольдштейна (1892-1953), вместе с которым была арестована в декабре 1947 и отправлена в лагерь, в поселок Явас Зубополянского района Мордовской АССР; мужа заключили во Владимирский централ, переписка им была запрещена, см.: Закурдаев 2013: 178-185. Вернулась в Москву, вероятно, в конце 1954 или начале 1955. В начале января 1956 ей сообщили о реабилитации мужа, но утаили, что его нет в живых, см.: ОР РНБ. Ф. 1393. Ед. хр. 640. Л. 15, об этом она узнала лишь спустя несколько месяцев: «Мне выдали справку о его полной невиновности, свидетельство о его смерти и его докторский диплом. Когда давали диплом, то сказали: “вот все, что осталось от Вашего мужа”» (ОР РНБ. Ф. 1393. Ед. хр. 640. Л. 18 об. Письмо к Б. В. Казанскому от 5 мая 1956). С большим трудом она получила комнату в коммунальной квартире, о которой писала Казанскому: «Живу я тут по-прежнему “в малине”, как выразился один мой знакомый (знаете этот воровской жаргон?). Привыкла к тому, что у меня вымогают деньги (потом отдают - ненадолго) и снова вымогают» (ОР РНБ. Ф. 1393. Ед. хр. 640. Л. 32 об. - 33. Письмо к Б. В. Казанскому от 9 марта 1961). 
таково, что работать спокойно не удается. Тут еще помешал мне наш переезд - мы перебрались на другую, более зимнюю дачу со всяческими удобствами, вроде<,> напр <имер $><,>$ ванны ${ }^{100}$.

Несмотря на это кое-что сделал. Эсхила приближаю к концу и надеюсь скоро приняться за Аристофана, о чем думаю с великой радостью. Если пойдет хорошо<,> то в лучшем случае начал бы магист<ерский> экзамен даже этой весной, хотя больше шансов за осень. Как видишь<,> скоро попасть к вам в Пермь мне бы не удалось, хотя я не могу сказать, чтобы мне это представлялось сейчас столь же нежелательным, как скажем год назад. И<,> разумеется, если придется ехать в провинцию, то уж лучше всего в Пермь, чтобы быть с вами вместе. Разлуки ощущаются в этом году особенно болезненно <..> срок их слишком неопределен, а формула «если будем живы» приобрела слишком конкретный смысл. Тем более обязательна повинность писать письма, особенно тем<,> кого это так интересует<,> как меня. Мне жалко, что Ты не пишешь конкретно о своей академической работе <...>. Я более точен в своем описании и если прибавлю, что начал учиться новогреческому <...> и что даю уроки латинского детям Винавера ${ }^{101}$, царя кадетов, то этим исчерпаю мой отчет. <...>

\footnotetext{
100 Ср. в письме А. Д. Радловой свекру от 23 октября 1917: «Дорогой Эрнест Львович <...> нас повергло в уныние прекращение пассажирского движения, которое предполагается ввести 10-ого Ноября. Когда-то мы будем в Петрограде и повидаем всех Bac? У нас все не очень ладно: мама все настаивает на том, чтобы мы переехали из Профессорского Уголка в Алушту или Ялту, т. к. она боится, что дом наш без двойных рам окажется холодным зимой. Если не будет слишком дорого переезжать, то весьма вероятно, что мы это осуществим. Мама же и сестры хотят куда-нибудь уехать. Думаю, что кончится дело тем, что все вернутся в Петроград, если будет фактическая возможность доехать. Сережа очень много работает <... » (ОР РНБ. Ф. 1393. Ед. хр. 1347. Л. 1-1 об.).

101 Максим Моисеевич Винавер (1862 или 1863-1926) - адвокат, публицист, один из основателей конституционно-демократической партии, депутат I Государственной думы, мемуарист. С апреля 1919 - в эмиграции во Франции. «Библиотека Винавера, в своей значительной части представленная прекрасным подбором гебраистики, после долгих мытарств и далеко не в полном составе поступила в Научную библиотеку Московского университета и, подобно другим частным книжным собраниям, растворилась в библиотечных фондах. Знаменательно, что на книжном знаке Винавера изображен вождь афинской демократии, стратег и законодатель Перикл»
} 
В республике ли мы украинской, ханстве крымском или румынском королевстве<,> еще как-то не разобрал. Впрочем<,> все они лучше скифского самодержавия большевиков. Об этом, однако, здоровее не думать. К этому прилагаем мы оба усилия<,> и в результате Анне удается плодотворно и значительно работать в поэзии ${ }^{102} .<\ldots>$

Новый адрес: Судакское шоссе,

Дача Батуева. <...> $>^{103}$.

(Бердичевский 2004: [http://judaica.kiev.ua/old/Eg_14/14-18.htm]). Дети Винавера: Валентина Максимовна Кремер (урожд. Винавер; 1895-1983, Париж) - доктор медицины, общественный деятель. Софья Максимовна Гринберг (урожд. Винавер; $1904-$ 1964) - юрист, общественный деятель, см.: Будницкий, Полян 2013: 431, 444. Михаил Максимович Винавер (1906-1920), умерший в отрочестве, см.: Кельнер 2018: 394. Евгений Максимович Винавер (1899-1979) - специалист в области средневековой французской литературы, в юности - член университетского кружка поэтов, в который входили В. А. Злобин, М. О. Лопатто, Д. Л. Майзельс, Г. В. Маслов, Ю. А. Никольский, Н. А. Оцуп, Л. М. Рейснер, В. А. Рождественский, Г. П. Струве, Е. М. Тагер, В. М. Тривус и др. Самый младший, Евгений Винавер, был, по воспоминаниям Тагер, инициатором кружка, см.: Богомолов 1988: 183. Организационное собрание кружка состоялось осенью 1915 как раз на квартире М. М. Винавера, на заседаниях кружка бывал Мандельштам, см.: Шруба 2004: 83. Е. М. Винавер - автор рецензии на издание «Посмертных стихотворений» И. Ф. Анненского (1923), см.: Тименчик 2017: 115-117. О кружке поэтов и о перечисленных лицах см.: Струве 1979: 13-28; Богомолов 2010: 503, 663; Тименчик 2017: 427-447. См. также очерк А. Л. Соболева о Майзельсе: Соболев 2013: 249-268.

102 Приведем отрывок из написанного Радловой в ноябре «Послания»:

Под незнакомым снеговым покровом

Покоится татарское село,

И, как полярный океан бело,

Несется море мертвое <...>

А вечером, когда поселок спит,

Шатобриана при свече читаю,

Иль молчаливо греюсь у огня.

Что называли некогда меня

Красивою, совсем позабываю.

Ты думаешь, что скучно я живу

И проклинаю вольное изгнанье,

А, может быть, теперь дано мне знанье,

Как надо петь покой и синеву.

1917. Ноябрь

(Радлова 1918: 21-22)

${ }^{103}$ ОР РНБ. Ф. 1393. Ед. хр. 713. Л. 14-Л. 15 об. 
Радловы остались зимовать в Крыму. В начале декабря 1917 А. Д. Радлова уехала в Ялту лечиться, 17 декабря муж писал ей:

Перед сном читаю Пушкина, уже лежа в постели. <...> Знаешь, в «Переписке» много где $<\ldots .>$ говорит о гордости предками. Так $<$ им $>$ обр $<$ азом ><,> что ни возьму в руки - Аристофана, Пушкина, - везде пью из чистых источников аристократического консерватизма. $<\ldots>$ Тебе внушение: в «Тарасе Бульбе» «веницейский», а Ты мне<,> дурачок<,> не верил ${ }^{104}$.

Вскоре до Алушты дошли слухи, что в Ялте неблагополучно. В большом письме от 5 февраля $1918^{105}$ Радлов сообщал сестре о произошедших событиях:

Моя дорогая Наташенька, мы не писали Тебе страшно долго и этому были причиной многие и серьезные события. Расскажу вкратце. В начале Декабря Нюрушка уехала лечиться в Ялту на месяц. 22 Дек<абря ><,> услыхав о начинающихся там беспорядках<,> я поехал к ней и провел 10 дней. Севастопольские матросы не ладили с Крымскими эскадронцами ${ }^{106}$. Но т $<$ ак $>$ к<ак $>$ ничего не произошло $<$,> и власть в Ялте осталась в руках татар<,> я вернулся в Алушту. 9 Янв<аря > узнаю, что Ялту взяли большевики и осадили татары. Я сразу же попытался пробраться в город пешком, но меня не пустили<,> и я 5 дней был в 9 верстах от Ялты <,> смотрел, как миноносец<,> стоявший у самого берега<,> вплотную расстреливал город и татар $<$,> засевших в некоторых домах во время наступления. $<\ldots>$ В это время Нюра была в самой настоящей опасности.

\footnotetext{
104 ОР РНБ. Ф. 625. Ед. хр. 668. Л. 55-55 об. Имеется в виду следующий фрагмент из «Тараса Бульбы»: «На полках по углам стояли кувшины, бутыли и фляжки зеленого и синего стекла, резные серебряные кубки, позолоченные чарки всякой работы: венецейской, турецкой, черкесской, зашедшие в светлицу Бульбы всякими путями, через третьи и четвертые руки, что было весьма обыкновенно в те удалые времена» (Гоголь 1952, 2: 34). Мандельштам воспользовался этим эпитетом в стихотворении «Веницейской жизни, мрачной и бесплодной...» (1920).

105 Год ставим по смыслу и ориентируясь на предшествующие письма.

106 Эскадронцы - военные части крымских татар.
} 
Улицу, где она жила, обстреливали особенно яростно. Один снаряд разорвался в комнате под <?> нею. Ночью она бежала из этого дома под пулеметами, вместе с Белокопытовыми (Анна Мих<айловна > должна была родить в эти самые дни, но родила после осады через 4 дня - девочку) в другой дом. Ее мужа чуть не расстреляли. 15 Янв<аря> я один из первых попал в Ялту после победы большевиков <,> и это испытание кончилось.

Вместо трагедии бытовая пьеса. Мы оказались почти без денег. Думали ехать в Петроград, но все не можем на это решиться из-за Митьки. <..> Митька поехал с Марией Ник<олаевной> в Симферополь и по дороге их ограбили - отрезали сзади все вещи меха $\mathrm{M<арии>} \mathrm{Ник<олаевны>,} \mathrm{все} \mathrm{Митькино} \mathrm{добро} \mathrm{и} \mathrm{т.} \mathrm{д.!}$

Затем нас стали удерживать новые угрозы и страхи. Здесь же есть довольно жалкая гимназия, кот<орая> даст нам возможность не сдохнуть с голоду при очень скучном труде.

Все это ставит мои магистерские экзамены под большой вопрос. Здесь начинается моя просьба к Борису. Пусть он серьезно подумает, нет ли возможности пристроить меня в Пермском университете в качестве ассистента или как это называется, на год<,> в продолжение которого я обязуюсь, живя <?> в более культурных условиях<,> сдать экзамены. Здесь у меня нет книг<,> и я ничего не могу поделать, а главное<,> мне негде сдавать экзамены. <...> Зелинскому я напишу соответственный запрос. Если это даст слишком мало денег, то<,> $6<$ ыть $>$ м<ожет $><,>$ найдется еще педагогическая работа <... или литературная и даже уроки для Нюрки. Было бы прекрасно, если бы удалось устроиться с Вами. <...> ${ }^{107}$.

Здесь же приписка Радловой карандашом:

Дорогая моя Наташа, из Сережиного письма ты знаешь о моих мытарствах Ялтинских. Чувствую я себя отвратительно, устала от всего и если бы не Сережа, вероятно, я считала бы себя совсем

107 ОР РНБ. Ф. 1393. Ед. хр. 1100. Л. 49-Л. 50 об. Часть письма Радлова, от слов «Моя дорогая Наташенька» до «это испытание кончилось», приводилась с неточностями, см.: Куранда 2016: 95-96. Мы цитируем по автографу. 
несчастной. Ужасны перспективы - торчать всю зиму и<,> м<ожет $>6<$ ыть $><,>$ и дальше в Алуште. Ну, авось как-нибудь выкарабкаемся. $<\ldots .>>^{108}$.

А вскоре Радловы возвращаются в Петроград, под «скифское самодержавие большевиков». Произошло это, вероятно, в начале, марта 1918, так как в штампе петроградского паспортиста стоит дата 12/25 марта $1918^{109}$. Адрес Радловых в это время - Васильевский остров, 8-я линия, дом 40.

Из Петрограда Радлов пишет сестре о своем положении 1 мая 1918:

Милая Наташенька, я очень виноват перед вами обоими, что не писал так долго. <..> Я до сих пор живу “пока”. Мы все еще в одной комнате, все еще не с нашей мебелью и главное все еще с неопределившимися занятиями. <..> Получаю стипендию, немного подрабатываю театральными рецензиями в “Биржевке” и надеюсь на лучшее будущее. Возможно, что оно придет скоро<,> и это опять работа в театре. Вокруг меня собрались несколько человек мейерхольдовцев, кот<орые> хотят со мною заниматься<,> и я уже начал кое-что с ними. <..> Нас зовут участвовать в спектаклях, но бесплатных, а на это я пойти не могу, ибо ищу заработка. Вижу только одно, что театр от меня не уйдет<,> и я не уйду от театра. <..> все равно что-нибудь искать придется<,> кроме университета; надо будет делать что-нибудь и Анне; - здесь все же благоприятное место для ее литературной деятельности. Книга ее печатается и, надеюсь, через месяц Ты уже ее получишь ${ }^{110}$. Наконец и экзамены все равно надо держать здесь. <..> вообще трудно расстаться с Петроградом. Тебе это удалось хоть в том смысле, что ты не закисла в провинции<,> а наоборот развернулась. Это одна из самых моих больших радостей за эту зиму. Ты пишешь, что читала лекции о театре. Мне бы очень интересно узнать<,> о чем именно и что именно.

\footnotetext{
108 ОР РНБ. Ф. 1393. Ед. хр. 1100. Л. 50 об.

109 См.: ОР РНБ. Ф. 625. Ед. хр. 3. Л. 2 об.

110 Первый сборник стихов Радловой «Соты» с посвящением мужу, см.: Радлова 1918: 5.
} 
Я очень вожусь с мыслью об актерской импровизации. Моя теза такова: современной драматургии мы не имеем, надо <1 слово нрзб.> изнутри и стать драматургами самим актерам. Это развивал я на днях на большом диспуте<,> устроенном К. М. Миклашевским (читала ли ты его книгу “Commedia dell'arte"?111 Если в Перми ее нет, я скажу ему, чтобы он послал ее в Ваш университет). Кроме этого<,> от слов перешел к делу и заставил своих учеников говорить ненаписанную пьесу. Выходит лучше, чем можно ожидать. $<\ldots>^{112}$.

Отвечая на письмо сестры, Радлов писал 20 мая 1918:

Моя дорогая Наташенька, Получил только что Твое письмо со вложением Гайдебурову ${ }^{113}$ и пользуюсь этим предлогом, чтобы Тебе ответить, что уже давно собирался. Просьбу Твою конечно исполню на днях, с каким успехом, это уже другой вопрос. <...> Для меня было большою радостью узнать, что Ты разлюбила Ибсена. Теперь мне действительно кажется, что Твой путь - истинный, не во внутреннем только смысле, где истинный путь всякий, на котором работаешь убежденно и честно, а в возможности создать объективные ценности искусства. <..>

Сам я кое-что делаю в театре, хотя как всегда, меньше чем бы надобно. В пустых комнатах «Аполлона» ${ }^{114}<\ldots>$ мне предложили устроить театр $<\ldots>$ деньги<,> хотя и не очень большие<,> на устройство дают, остается только устраивать и получать потом если удастся! - доход. Но всякие <?> административные хлопоты мне ненавистны<,> и я твердо решил от них отстраниться. Пока же репетирую Еврипидова «Киклопа» <...> Киклоп - огромный актер

111 Радлов читал эту книгу в Алуште, в декабре 1917, см.: ОР РНБ. Ф. 625. Ед. хр. 668. Л. 37 об.

112 ОР РНБ. Ф. 1393. Ед. хр. 1100. Л. 53. Л. 53 об.

113 Павел Павлович Гайдебуров (1877-1960) - актер, режиссер, театральный критик, мемуарист, один из создателей Передвижного драматического театра, где некоторое время играла Н. Э. Казанская.

114 Редакция журнала находилась на Разъезжей ул., 8. 
в маске с громадным глазом. (Смотреть он будет через ноздри своей хари). <...>

С этими же моими учениками-актерами начал ставить по моему сценарию импровизационную пьесу, несколько в стиле италианском, но с примесью современности. Кстати<,> об импровизации - чтобы нащупать технику <1 слово нрзб.><,> почитай во французском переводе Квинтилиана кое-что в книгах VI и VIII, да и в других, а то Цицерона de l'invention и de l'orateur. $<\ldots>$ Я убежден, что мне <4 слова нрзб.> два рода занятий 1) конспекты на разные темы - любви, ненависти, ревности и т. д. с указанием того<,> что может пригодиться в любом таком монологе (чтобы знать<,> о чем говорить). 2) писать как можно больше синонимических выражений - ласки, ругани и т<ому> под<обного $><$,> чтобы знать что говорить и не лезть за словом в карман.

Кроме этих занятий мне через Мейерхольда предлагают режиссировать в коротких спектаклях - думаю, что не откажусь<,> ибо считаю эту работу полезной, а тем самым и почетной $<\ldots>^{115}$.

Театр, который предложили устроить Радлову, - это Театр экспериментальных постановок, где летом 1918 режиссер поставил два спектакля. В недатированном письме к Н. Э. Казанской Радлов писал:

<..> постараюсь оправдаться в постыдном неисполнении поручений. Я несчетно звонил по телефонам и искал адреса Гайдебурова $<\ldots>$ Список Борисовых книг показывал универс<итетскому> библиотекарю <...> Такое количество книг может быть утверждено только факультетским заседанием. <..> У нас все хворают и вообще грустно, холера не столько пугает<,> как угнетает и лишает столь <1 слово нрзб.> возможность разнообразия. Митюшку отправили, слава Богу, под Лугу, хоть и очень скучно без него, но я рад, что он не здесь ${ }^{116}$.

\footnotetext{
115 ОР РНБ. Ф. 1393. Ед. хр. 1100. Л. 54. Л. 54 об. Л. 55-55 об.

116 ОР РНБ. Ф. 1393. Ед. хр. 1100. Л. 52-52 об.
} 
И добавлял в постскриптуме:

Я поставил «Сбитенщика» Княжнина ${ }^{117}$ - лубок, однако отнюдь не утрированный, сейчас ставлю «Близнецов» в масках. Начал репетировать Еврипидовскую Алкесту<,> но пока отложил за трудностью ${ }^{118}$.

По всей вероятности, в конце лета 1918 Радлов написал большую статью «О технике греческого актера», в которой цитировал упомянутых в письме к сестре авторов - Квинтилиана, Цицерона и Миклашевского - и, в доказательство своих теоретических положений, сообщал читателю о постановке «Близнецов»:

Я не хочу непременно утверждать, чтобы амплуа актеров делились по тембру голосов (впрочем, и это возможно, хотя бы потому, что актерам приходилось петь, и вряд ли музыкальный афинянин стал бы слушать подряд трех баритонов или теноров); но важна была полнейшая идеальная согласованность сложного голосоведения <..> мы не знаем, насколько умели греческие актеры менять голос в разных ролях, но думаем, что зритель, привыкший к исполнению женских ролей мужчинами, легко мирился и с этой новой условностью: ведь мы имеем дело не с натуралистическим театром и этим все сказано $<\ldots>$ Но, возразят нам, каково же было актерам бегать за сцену, переодеваться, снова вылетать и говорить в течение трех или четырех пьес? Не могу умолчать, что я пишу это под впечатлением ближайшего опыта моей постановки Плавтовых «Менехмов», где один актер играл три роли, трижды меняя голос. Все же я охотно верю, что участие в трех трагедиях подряд было бы трудом непосильным для современного актера, и для этого нужно было развитие атлетическое, но актер и был атлетом; недаром в жизни профессиональных союзов «синоды

117 «Сбитенщик» (1783) - комическая опера Я. Б. Книжнина.

118 ОР РНБ. Ф. 1393. Ед. хр. 1100. Л. 52 об. В октябре 1918, составляя проект реорганизации театра, режиссер писал о постановке «Близнецов»: «<...> опыт<,> признанный удачным как людьми искусства (Мейерхольд, Миклашевский, Кузмин)<,> так и представителями филологической науки (Зелинский, Малеин <...>)» (ОР РНБ. Ф. 625. Ед. хр. 212. Л. 2 об.). 
ремесленников Диониса» упоминаются рядом с корпорациями иных атлетов (Радлов 1918: 14-15, раздел 5).

С июня 1918 Радлов преподавал филологические дисциплины на Курсах мастерства сценических постановок (Курмасцеп), организованных Мейерхольдом, и возглавил их после отъезда Мейерхольда на юг летом 1919 (см.: Золотницкий 1999: 13).

13 октября 1918 в письме к сестре он делился своими успехами:

Дорогая моя Наташенька, $<\ldots>$

Сейчас я могу сказать определенно, что я в периоде удач, настолько, что я чувствую себя более уверенным в своей счастливой звезде, чем способностях<,> искусстве и опыте. Меня позвали теперь постоянным режиссером в Больш<ой $>$ Нар<одный $>$ Дом<,> и я рад этому, потому что необходимо поработать в большом и сложно оборудованном театре, чтобы освоиться с режисс<ерской> техникой, необходимо и ухватиться и за второй постоянный заработок, т<ак> к<ак> здесь без тысяч в месяц не прожить<,> и затем это приятное для меня доказательство некоторой моей репутации, созданной постановкой «Близнецов» ${ }^{119} .<\ldots>$

Впрочем<,> чувствую, что мой первый блин будет комом - мне приходится ставить Марию Стюарт<,> и я только теперь понял, до чего это слабая и театрально пустая пьеса, в которой нет ничего<,> кроме “благородной” декламации и характеров, либо элементарных, либо туманных.

Здесь мне надо работать во «вчерашнем» театре, но я верю, что моя студия ${ }^{120}$ - это «завтра» театра. Ты знаешь, мне удалось уже осуществлять импровизованные пьесы<,> и мои актеры сыграли две маленьких и сыграли очень гладко и уверенно. Я чувствую здесь громадные возможности и верю, что если мне удастся создать импровизованную пьесу на тему современности (не политической<,> конечно), то это будет настоящим событием в нашем театре. $<\ldots>$

119 В 1919 в Одессе «Близнецов» «в масках» поставил Миклашевский, см.: Янгиров 1996: 407.

120 Театр экспериментальных постановок. 
Мне приходится встречаться с очень милыми людьми, подчас интересными, но схожусь я с ними как всегда очень туго. Из всех их мне очень дорог Блок, с кот<орым> я за последнее время встречаюсь все чаще. В нем громадное и несравненное очарование. $<\ldots>^{121}$.

Неизвестно, когда именно Радлов познакомился с Блоком, но еще в 1913 поэт записывал, что Мейерхольд прислал ему стихи Радлова выбрать для публикации в журнале «Любовь к трем апельсинам» (см.: Блок 1965: 202)122. С Блоком Радлов виделся и на службе, в репертуарной секции Театрального отдела Наркомпроса, где он был секретарем, а Блок - председателем (см.: Иванова 2012: 243), и дома у поэта (см.: Блок 1965: 434, 436).

В ноябре 1919 Театральный отдел Наркомпроса предложил Радлову и В. Н. Соловьеву создать Театр художественного дивертисмента, вскоре переименованный в Театр Народной комедии. Он открылся 8 января 1920 в петроградском Народном доме (см.: Купцова 2000: 578). Труппа театра была сформирована из драматических и цирковых артистов, с осени 1920 в нее вошла Л. Д. Блок, по сцене Басаргина (см.: Золотницкий 1999: 32). В спектаклях Театра Народной комедии использовались цирковые приемы (акробатика, различные аттракционы, любимая режиссером пантомима), большое значение придавалось эксцентрике и мелодраматическим эффектам. Режиссер, вспоминала современница, «набрал в труппу несколько циркачей, считая, что новому зрителю, в основном матросам и красноармейцам, легче будет воспринимать спектакли, где меньше монологов и переживаний, а больше кульбитов, сальто и проч. акробатических номеров» (Миклашевская, Катерли 2007: 127).

Одним из актеров и авторов Театра Народной комедии стал Миклашевский. Его пьесу «Последний буржуй, или Музей старого строя» Радлов поставил в июле 1920, впрочем, о пьесе можно говорить лишь условно. Сам Миклашевский вспоминал спустя несколько месяцев после постановки:

\footnotetext{
${ }_{121}$ ОР РНБ. Ф. 1393. Ед. хр. 1100. Л. 56. Л. 56 об. - Л. 57.

122 Одно из стихотворений («Я верю, объятья жарки, я верю, лобзанья жгучи...» было напечатано, см.: Радлов 1914а: 8-9.
} 
Я пришел в театр, имея в голове сюжет, несколько трюков, несколько острот и только. Многое придумали актеры, и если все-таки многое подсказано автором, то это не исключает импровизации, хотя репетиций было около 15-ти. <..> Текст так и оставался незаписанным, пока после 12-го спектакля И. М. Лапицкий ${ }^{123}$ не попросил у меня пьесы для Москвы, где она идет сейчас <...> (Чжиен 2000: 119).

Радлов сам писал комедии для своего театра, по его собственным подсчетам за два с небольшим года существования театра режиссер написал десять или двенадцать пьес (см.: Радлов 1994: 85). Приведем несколько названий: «Обезьяна-доносчица», «Невеста мертвеца», «Пленник», «Султан и черт», «Приемыш», «Вторая дочь банкира», «Любовь и золото». За основу часто брались итальянские сценарии восемнадцатого века и французские цирковые пантомимы девятнадцатого века, в частности, Жана-Гаспара Дебюро ${ }^{124}$ (см.: Там же: 93; комментарий П. В. Дмитриева). Спустя почти двадцать лет Радлов вспоминал: «Я писал сценарии, а циркачи и драматические актеры импровизировали. Когда им становилось невмоготу, я на репетиции брал карандаш и бумагу и писал монологи» (Там же: 85-86). В это же время режиссер «археологически увлекся шекспировской сценой <..> и желанием ее реставрировать» (Там же: 88). В театре шли также переделки «Виндзорских проказниц» Шекспира, «Господина де Пурсоньяка» Мольера и «Саламейского алькальда» Кальдерона под названием «Деревенский судья» (см.: Там же: 98, 99).

Возглавляя Театр Народной комедии, Сергей Радлов принял активное участие в знаменитых массовых петроградских празднествах 1920. Расскажем о двух из них в нескольких словах.

В праздновании 1 мая 1920 участвовали около двухсот театральных групп. Вот как это происходило:

\footnotetext{
123 Иосиф Михайлович Лапицкий (1876-1944) - режиссер.

124 Жан-Гаспар Дебюро (Deburau), прозванный Жан-Батист (1796-1846), - знаменитый французский мим, выступавший в роли Пьеро на подмостках парижского театра Фюнанбюль (Funambule). Персонаж фильма Марселя Карне и Жака Превера, написавшего сценарий, «Дети райка» (1945).
} 
«С утра двенадцать <трамвайных> вагонов с прицепленными к ним грузовыми площадками, которые посредством разноцветных фанерных щитов и размалеванных холстов <... были превращены в пестрые балаганы» (История советского театра 1933: 268), тронулись в путь от Летнего сада. Комендант маршрута площадки номер семь - Радлов - повез труппу Театра Народной комедии показывать рабочим «Обезьяну-доносчицу» и «Происки капиталистов». По свидетельству Л. В. Шапориной, в этот же день и ее кукольный театр давал представление. На площадке около Кофейного домика в Летнем саду шел спектакль, поставленный Радловым, «Емеля на войне, или Разговор русского с немцами» (см.: Шапорина 2011, 2: 432). Вряд ли любителю «чистых источников аристократического консерватизма» легко давались эти постановки.

20 июня 1920 на Каменном острове, только что переименованном в «остров отдыха», Радлов поставил спектакль «Блокада России».

«Для этого спектакля был сооружен большой амфитеатр на берегу озера, а “сцена” была расположена посреди озера на островке, соединенном выгнутым мостом с берегом. Действие буффонно-сатирического обозрения развертывалось на острове, на мосту и на самом озере, по которому шнырял “блокирующий” Россию игрушечный броненосец и по которому шествовали десятки окрыленных разноцветными парусами лодочек в апофеозе» (Мокульский 1929: 10-11). Исполнителями были актеры Театра Народной комедии и красноармейцы, всего около 750 участников. Число зрителей доходило до десяти тысяч человек. «Действие было условно-историческим и делилось <..> на три отделения: 1) интервенция Антанты; 2) нашествие Польши; 3) торжество всемирного Интернационала» (История советского театра 1933: 283 284).

Спустя несколько дней после майского празднества Радлов получил от сестры телеграмму, в которой она сообщала об аресте Б. В. Казанского. О причине ареста ничего неизвестно, условия тюремного содержания можно представить себе по нескольким цитатам из недатированных писем филолога к жене: 
Сегодня меня перевели в Рабочий дом за Сиб<ирской> Заставой. Сюда и нужно носить посылку т<ак> наз<ываемую> «передачу». Пожалуйста<,> пришли мне немного крепкого табаку - приходится угощать соседей, - и коробок спичек, хлеба. <...> Я здоров, не беспокойся<,> и мне не так плохо, как может казаться посетителю, это вроде теплушки или плохой постановки На Дне, очень любопытно. <..>

При приеме мне сказали, что мне ставят в вину, что я стоял в списке кандид<атов> в Гор<одскую> Думу, хотя я и возражал, что я не кадет. Будто бы это по распоряжению ВЧК (из Москвы?). Если последнее верно, дело осложняется и желательно уладить его<.> $<\ldots>$ Живу я<,> не принимая все окружающее всерьез, а как к декорациям пьесы <sic! - M. C.>, но если затянется эта жизнь, то конечно будет тяжко. <..> Пришли еще ложку деревянную<.> Здесь гораздо лучше: там я спал на коротком столе, здесь на навесной койке, можно гулять во дворе <...>.

Мне так совестно за возню со мной и из-за меня, я представляю себе, как тебе это трудно, милый друг мой. <...> Я очень скучаю по тебе, голубчик мой. Спасибо за книги, но я хотел Цицерона речь маленькую без переплета в зеленой обложке, и еще, если Обнорский даст английский роман «Человек в углу» ${ }^{125}$, потом Bédier Les fabliaux ${ }^{126}$, в переплете. Как мне хочется тебя видеть, поговорить, поцеловать, но свиданья<,> вероятно $<,>$ нельзя добиться. Хорошо и то, что ты пишешь. <... М<ожет $>6<$ ыть $><,>$ удастся меня взять на поруки. Целую тебя крепко и маму<,> и детей. Навещать меня нельзя, разрешен<и>я от ЧК трудно получить. А тут до допроса многие сидят по месяцам. <...> ${ }^{127}$.

\footnotetext{
125 Вероятно, имеется в виду сборник из двенадцати детективных рассказов “The Old Man in the Corner" (1908; в американском издании "The Man in the Corner") английской писательницы, венгерки по происхождению, автора пьес, исторических и детективных романов баронессы Эммуски Орчи (1865-1947). Сергей Петрович Обнорский (1888-1962) - лингвист, декан историко-филологического факультета в Пермском университете, впоследствии академик.

126 "Les Fabliaux, études de littérature populaire et d'histoire littéraire du Moyen Âge » (1893) - неоднократно издававшийся труд филолога-медиевиста Жозефа Бедье (Charles Marie Joseph Bédier; 1864-1938).

127 ОР РНБ. Ф. 1393. Ед. хр. 1052. Л. 96. Л. 96 об. Л. 97. Л. 98. Л. 99.
} 
8 мая 1920 Радлов откликался на горестное известие:

Милая моя родная девочка, <..> Я получил твою телеграмму только во вторник <...> Пока мне удалось сделать вот что: я написал в Москву О. Д. Каменевой, жене крупного политического деятеля, письмо<,> которое пошло туда с оказией - в Среду утром. $<\ldots>$ Сообщил М. Ф. Андреевой и Максиму Горькому. Он обещал тоже написать в Москву, по-видимому<,> Дзержинскому. Кроме того<,> я передал Горькому и Андреевой недавно полученное нами декабрьское письмо от Бориса, из которого ясно<,> как плохо он стал относиться к колчаковскому режиму еще до прихода в Томск Красных войск. $<\ldots>^{128}$.

По-видимому, в двадцатых числах мая Б. В. Казанского выпустили из ЧК, в письме к Э. Л. Радлову от 23 мая 1920 (дата почтового штемпеля) Н. Э. Казанская сообщала, что муж с нею ${ }^{129}$.

В 1919 младший брат Мандельштама, Евгений Эмильевич Мандельштам (1898 - 1979), женился на свояченице Радлова, Надежде Дмитриевне Дармолатовой (см.: Мандельштам Е. 1995: 146, 177). В своих воспоминаниях он пишет о помощи, которую ему оказала семья Радловых, когда в 1922 его арестовали:

Сестра Надюши Анна и ее муж Сергей Радлов обратились за помощью к М. Горькому. Благодаря его заступничеству и поручительству следствие было ускорено. В результате меня приговорили только к шести месяцам принудительных работ, обвинив в контрреволюционной агитации, которой я, естественно, никогда не занимался (Мандельштам Е. 1995: 154).

\footnotetext{
128 Там же. Ед. хр. 1100. Л. 58-58 об. О выступлении Н. Э. Казанской, декламировавшей стихотворение Н. С. Гумилева на концерте в Перми в феврале 1919 в присутствии А. В. Колчака, см.: Тименчик 2018: 78.

129 См.: ОР РНБ. Ф. 1393. Ед. хр. 1349. Л. 9 об. За Казанского хлопотали и в Перми. Историк Н. П. Оттокар, коллега Казанского по Пермскому университету, писал его жене 29 апреля: «щМногоуважаемая Наталия Эрнестовна. Очень извиняюсь, что не мог ответить Вам раньше. Сегодня коммунистическая ячейка решила поддержать мое ходатайство о Бор<исе $>$ Вас<ильевиче > перед Всероссийской Чрезв<ычайной $>$ ком<иссией>. <...> (Там же. Ед. хр. 1092).
} 
В начале 1922 Театр Народной комедии закрылся, Радлов стал преподавать на режиссерском отделении Института сценических искусств ${ }^{130}$ и руководить актерской мастерской. В учебных спектаклях он «разрабатывает все те же вопросы движения на сцене, приемы театрального эксцентризма, буффонады и гротеска, технику массовых сцен» (Мокульский 1929: 15). Тогда же режиссер «устроил у себя на квартире нечто вроде театральной лаборатории» (Золотницкий 1999: 39), в это время Радловы жили на 1-й линии Васильевского острова, в доме 40. Лаборатория-студия просуществовала до весны 1924 (см.: Там же: 47).

Тут следует вспомнить о группе петроградских литераторов, назвавших себя «эмоционалистами» и писавших о своей связи с эстетикой западного экспрессионизма (в группу входили К. К. Вагинов, М. А. Кузмин, Радлова, А. И. Пиотровский ${ }^{131}$, Ю. И. Юркун). Группе удалось издать три выпуска альманаха «Абраксас» ${ }^{132}$. Во втором выпуске появились стихотворения Мандельштама «Как растет хлебов опара...» и «Ветер нам утешенье принес...» (см.: Мандельштам 1922: 17) и пьеса Радлова «Убийство Арчи Брейтона», напечатанная «на правах рукописи» (см.: Радлов 1922: 51-57).

Пьеса была несколько раз показана «узкому кругу зрителей в январе-феврале 1923 года, без декораций, костюмов и грима» (Золотницкий 1999: 42). В спектакле, проходившем «на площадке Института истории искусств (Исаакиевская площадь, 5) ${ }^{133}$, где ее показывали не однажды» (Золотницкий 1999: 42), участвовали

\footnotetext{
${ }^{130}$ В 1926 его переименовали в Техникум сценических искусств.

131 Адриан Иванович Пиотровский (1898-1937, расстрелян) - внебрачный сын Ф. Ф. Зелинского, драматург, литературовед, переводчик.

132 О группе «эмоционалистов» и об альманахе «Абраксас» см.: Никольская 1986: 61-70; Никольская 1990: 173-180; Морев 1997: 363-376; Тимофеев 1997: 190-205; Пахомова 2017: 115-126. О цели нового течения объявлялось в декларации, написанной М. А. Кузминым: «<..> эмоционализм <..> стремится к распознаванию законов элементарнейшего, видя в высокой элементарности противововес великолепным формам восхитительнейших соблазнов европеизма» (Никольская 1986: 63). См. также рецензию на «Абраксас» Шнюспельпольда (псевдоним Б. В. Горнунга), опубликованную в машинописном журнале «Гермес» в 1923 и републикованную в: Левинтон, Устинов 2001: 331-332. 133 В Институте истории искусств часто проходили вечера современной драматургии, подробнее см.: Тимофеев 1997: 202-203.
} 
члены радловской домашней студии, один из которых вспоминал и о занятиях и об одном из домашних представлений пьесы.

«Радлов пытался найти театральный “философский камень” в области неких “чистых элементов” театрального действия: “чистое движение”, “чистый звук”, “чистая эмоция”. <...> “Чистое движение” это экзерсисы на максимальную скульптурную выразительность человеческого тела, причем используются разнообразные смещения “осей”, проходящих через голову, плечи, бедра и голени. <...> “Чистый звук” - тренировка на сочетание бессмысленной речи, заумного языка с “чистой эмоцией”. <...> Помню его менторские возгласы:

- Послушайте, что вы там рассказываете? Мне не нужно смысла в вашем звучании. Вы опять нагружаете речь каким-то содержанием. Отдавайтесь эмоции безотчетно.

<..>> В пьесе, чисто экспрессионистической, действие развивалось не линейно, а “концентрическими кругами”, то есть было

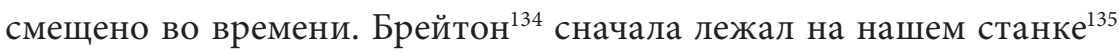
убитый, потом действовал живой; <..> Философский замысел пьесы, а соответственно и сюжетное ее решение, насколько я могу судить теперь, заключались в психологическом нагнетании чувства бессмысленности и безрезультатности преступления, а не в самом факте убийства. Нравилась нам эта пьеса чрезвычайно» (Голубенцев 1967: 165, 166, 167).

Н. Я. Мандельштам вспоминала, как в 1922 они с Мандельштамом пришли к Радловым и те уговаривали поэта присоединиться к их группе эмоционалистов.

Там собрались Кузмин с Юркуном и, кажется, с Оленькой Арбениной, художник Лебедев, муж второй сестры - Сарры Дармолатовой или Сарры Лебедевой, будущего скульптора, и еще несколько человек, и я опять услышала, как Мандельштама заманивают в объединение или союз - на этот раз синтеза всех искусств - поэзии, театра, живописи... Сергей Радлов, режиссер, с полной откровенностью объяснил Мандельштаму, что все лучшее

\footnotetext{
134 Мемуарист пишет «Брайтон», исправляем по «Абраксасу».

135 Станок - каркас из деревянных рам, на которые положен настил.
} 
в искусстве собрано за его чайным столом. Вот лучшие поэты, художники, режиссеры... <...> Материальная база - театр, который обеспечит и Мандельштама, как и других членов объединения. Имя Мандельштама необходимо для укрепления художественной ценности союза, он же получит поддержку группы во всех смыслах и во всех отношениях... Наконец Радловы, оба - и муж, и жена, задали вопрос напрямик: согласен ли Мандельштам позабыть устаревший и смешной акмеизм и присоединиться к ним, активным деятелям современного искусства, чтобы действовать сообща и согласованно? Мандельштам сказал, что по-прежнему считает себя акмеистом, а если это кажется кому-нибудь смешным, то ничего не поделаешь... (Мандельштам Н. 1990: 105, 106).

В фонде С. Э. Радлова в отделе рукописей РНБ сохранились автографы двух мандельштамовских стихотворений 1922: «Я по лесенке приставной...» и «Я не знаю, с каких пор...» ${ }^{136}$.

Эпизодическое общение Радлова и Мандельштама продолжалось, они встречались и в Москве, о чем свидетельствует письмо режиссера к жене от 7 июля 1923: «<...> Третьего дня был у Осипа [Мандельштама], он взял твои стихи и обещал их устроить <...> (Летопись 2016: 232).

В 1923 Мандельштам перевел драму немецкого революционера и писателя-экспрессиониста Эрнста Толлера «Человек-масса». В том же году Радлов на сцене Акдрамы (Александринского театра) поставил пьесу Толлера «Эуген Несчастный», премьера состоялась 15 декабря 1923 (подробнее см.: Никольская 1990: 176).

136 См.: ОР РНБ. Ф. 625. Ед. хр. 755. Л. 1, 2. Оба стихотворения написаны простым карандашом по новой орфографии на двух листах нелинованной бумаги, причем верхняя часть первого листа оторвана. Стихотворения пронумерованы автором, первым идет «Я по лесенке приставной...». В нем не семь строф, а шесть (отсутствует строфа «Распряженный огромный воз...»). Во втором стихе первой строфы стоит не «всклоченный», а «склоченный», в третьем стихе шестой строфы после «Распростились» стоит не двоеточие, а тире. В стихотворении «Я не знаю с каких пор» третья строфа записана в редакции, которая публиковалась в прижизненных изданиях, а теперь печатается в разделе «другие редакции», см.: Мандельштам 2009, 1: 462. В четвертой строке третьей строфы после синтагмы «тмин зашит» стоит вместо точки двоеточие. В четвертой строфе после последнего слова «сон» стоит не точка, а многоточие. 


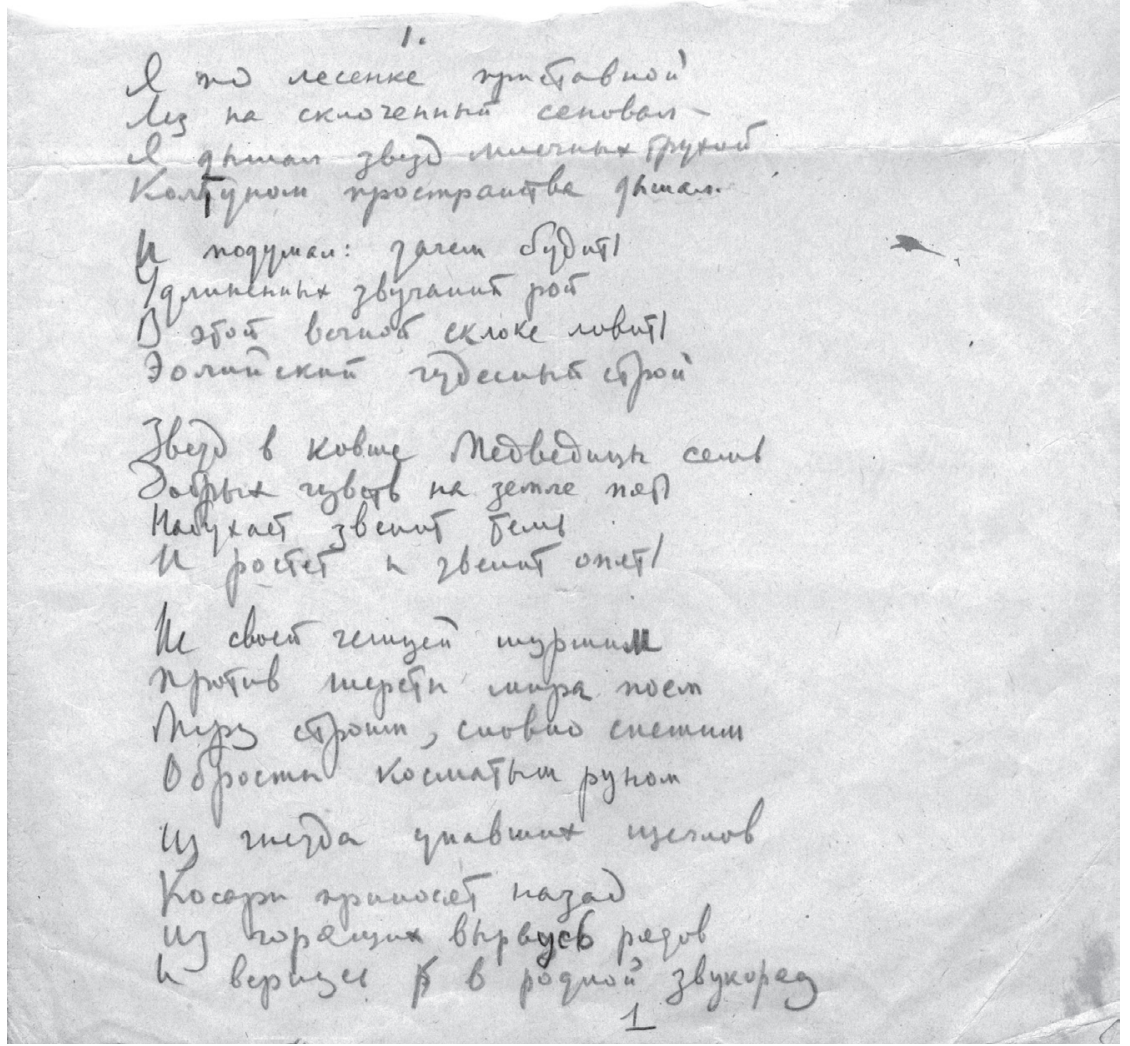

Автограф стихотворения Мандельштама «Я по лесенке приставной...» (ОР РНБ. Ф. 625. Ед. хр. 755. Л. 1)

Неизвестно, видел ли Мандельштам какие-либо постановки Радлова. В статье «Березиль (Из киевских впечатлений)» (1926) он пишет о спектаклях украинского театра, об обезьяньих лапах «экспрессионизма и театрального лжесимволизма» (Мандельштам 2009-2011, 3: 220), о толлеровщине, о неограниченном деспотизме современного режиссера и угнетении рядового актера, превращенного в сомнамбулу. Процитированные определения вполне могут быть отнесены к творчеству Радлова 1920-х, в основе которого были не только двойственность отношения филологаклассика с театром, но и противоречие между впитанным в юности 


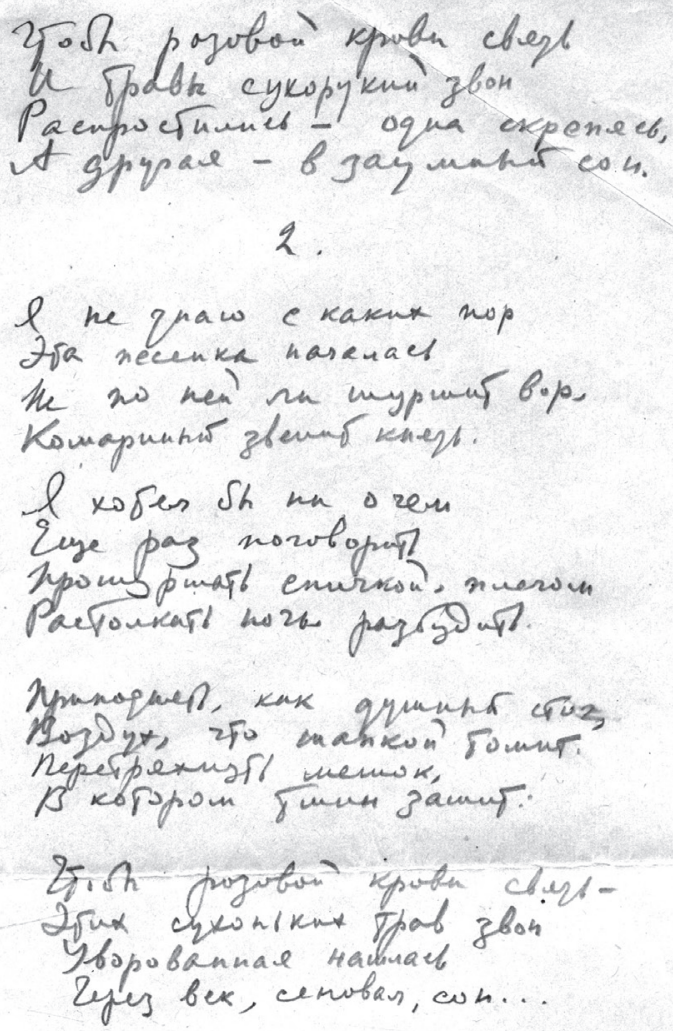

1922.

O. hangetintor.

Автограф стихотворения Мандельштама "Я не знаю, с каких пор...» (ОР РНБ. Ф. 635. Ед. хр. 755. Л. 2) 
отношением к искусству и его собственными театральными постановками, двойственность восприятия времени, присущая, впрочем, не одному Радлову.

В 1930 к XVI съезду ВКП(б) Радлов подготовил инсценировку «Развернутым фронтом», литературный материал предоставили Н. Н. Асеев и О. М. Брик. Приведем по архивным материалам план этой работы:

Порядок эпизодов.

1. Рапорт ударных бригад

2 Парад-алле прогульщиков, пьяниц, симулянтов и всех вредителей промфинплана.

3. Выход ударников.

4. Отрезвление пьяниц, разоблачение симулянтов.

5. Сборка трактора в деревню.

6. В тисках трехполья.

7. Сметем трактором межи.

8. Бой трактора с кулаком.

9. «В колхоз пошел середняк»

10. О курах, поросятах и о лядях $<$ sic! - M. C.> с нетвердыми головами.

11. Пара веских цитат.

12. Рапорт обобществленных полей и районов сплошной коллективизации.

13. Враг грозит.

14. Не позволим сорвать социалистическое строительство.

ПЕРЕХОД К РЕКЕ.

15. Гиганты социалистической стройки.

16. Разведка врага (Глиссера).

17. Враг наступает.

18. «Нас побить, побить хотели».

Десант врагов, бой и победа $K<\mathrm{p}>$ асной Армии.

Река и противоположный берег.

19. С нами пролетариат и революционные колонии всего мира ${ }^{137}$.

137 ОР РНБ. Ф. 625. Ед. хр. 238. Л. 14-14 об. 
В ноябре 1928 на Троицкой улице, $18^{138}$ открылся Молодой театр, возникший из двух выпусков уже упоминавшегося Техникума сценических искусств - группы Радлова и группы В. Н. Соловьева (см.: Золотницкий 1999: 116). Первой его постановкой были «Близнецы» Плавта (еще в апреле режиссер «проверил новый спектакль на квалифицированной аудитории Института истории искусств» (Там же: 118), спектакль шел под музыку Кузмина). В 1933 Радлов поставил «Привидения» Ибсена, годом раньше - «Отелло». В 1934 Молодой театр был переименован в Театр-студию под руководством Радлова, в том же году состоялась премьера «Ромео и Джульетты» в переводе А. Д. Радловой. Как пишет исследователь, «Курс на оптимизм был взят в пределах трагических ситуаций действия. <..> Эпизоды действия скреплялись или перебивались интермедиями на просцениуме, часто пантомимными, часто смешными» (Там же: 144).

9 сентября 1933 коллегия Наркомпроса постановила присвоить Радлову звание заслуженного артиста Республики ${ }^{139}$.

К 1935 относятся самые громкие московские постановки режиссера: «Отелло» вышел в новой редакции в московском Малом театре, и режиссер написал, что «начал нащупывать тот основной и единственно мыслимый для нас подход к Шекспиру как драматургу реалистическому, который сделался для меня руководящим в моих дальнейших работах...» (Золотницкий 1999: 127). В Государственном еврейском театре был поставлен «Король Лир» с Михоэлсом в главной роли ${ }^{140}$.

В 1938 Радлов в своем театре поставил «Гамлета», первую рецензию на спектакль написал давний друг А. А. Смирнов (см.: Золотницкий 1999: 208), а спустя два года вышла книга, целиком посвященная анализу спектакля. Ее автор писал: «Все лучшие постановки Радлова за последние пять-шесть лет - это его шекспировские работы. <...> Режиссер, вышедший из академической

\footnotetext{
138 Ныне улица Рубинштейна.

139 См.: ОР РНБ. Ф. 625. Ед. хр. 3. Л. 6.

140 См. переписку Радлова с Михоэлсом и комментарий: Иванов 2009: 506-532.
} 
среды $<\ldots>$, он отлично знает историю елизаветинской Англии, все особенности эпохи, ее быт, ее художественную культуру. И конечно, он хорошо знает и чувствует елизаветинский театр» (Березарк 1940: 14-15). «“Пьеса 'Гамлет', - говорит Радлов, - если перевести на современный язык, это пьеса об интеллигенции, о передовых мыслящих людях того времени"» (Там же: 32).

Спектакль шел в переводе Анны Радловой, рецензент отметил его особенности: «<...> недостатки перевода "Гамлета" <..> определяются не грубостью, а тем, что этот перевод не до конца насыщен глубокой философской мыслью. <...> Лучше всего удаются Радловой сцены специфически игровые <...> сцены, полные бурной страсти. Ярко и образно переведены также прозаические сцены - бытовые и сатирические. <..> Если в спектакле отразились особенности творческой работы Анны Радловой, то, с другой стороны, самый замысел спектакля, по-видимому, в какой-то мере повлиял на стиль ее перевода. Между режиссером и переводчиком здесь было тесное взаимодействие; они работали совместно, совместно они создавали спектакль...» (Там же: 44, 45).

В 1939 театр стал называться театром имени Ленинградского Совета $^{141}$, он работал и в блокадном Ленинграде. 3 декабря 1941 состоялась премьера «Дамы с камелиями» (см.: Золотницкий 1999: 233). Радловы с сентября 1941 жили в помещении театра, в январе 1942 из-за отсутствия света он закрылся (см.: Шапорина 2011, 1: 300), а в марте 1942 был эвакуирован в Пятигорск. Туда же был эвакуирован и ленинградский Театральный институт (ныне РГИСИ), «выросший» из Техникума сценических искусств.

9 августа в Пятигорск вошли немецкие войска. В ночь на восьмое августа часть труппы «удалось отправить на машинах из станицы Горячеводской в Нальчик» (Золотницкий 1999: 242). Транспорт для полутора десятков человек смог раздобыть В. Я. Чобур $\mathrm{p}^{142}$. Он вспоминал, что у А. Д. Радловой был сердечный приступ, и Радлов

\footnotetext{
141 Не путать с доныне существующим в Санкт-Петербурге театром им. Ленсовета.

142 Вольдемар Янович Чобур (1910-1981) - актер. См. публикации писем Радлова к нему из лагеря: Гайдабура 1992 (фрагменты); Гайдабура 2009.
} 
сказал, что она не сможет ехать на грузовике (см.: Там же: 242). Большая часть труппы осталась в Пятигорске. В своей книге о Радловых В. М. Гайдабура приводит слова завлита БДТ Д. М. Шварц:

Діна Морицівна Шварц, яка також побувала у війну в П’ятигорську, холодно відрізала: “Не було транспорту? Могли 6 і пішки бігти 3 П’ятигорська, як це зробили ми, студенти Ленінградського театрального інституту. Ось вам і вся історія" (Гайдабура 2009: 13)143.

В оккупации театр ставил оперетты, мелодрамы, в конце 1942 Радлов выпустил премьеру - «Гамлета» (см.: Золотницкий 1999: 252). Играли также «Без вины виноватые», «Бесприданницу», «Даму с камелиями», в ней в роли Дюваля-отца постоянно выступал сам Радлов, в других спектаклях он часто заменял больных актеров (см.: Там же: 255).

В начале февраля 1943 оккупанты вывезли труппу в Запорожье, театр стал называться «Петроградский театр под руководством Радлова» (см.: Там же: 254). В сентябре 1943 труппу перевезли в Берлин. Театром занялась фашистская пропагандистская организация «Винета» ${ }^{144}$, ведавшая, в том числе, и «культурным обслуживанием рабочих, угнанных из СССР в рейх» (Гайдабура 1992: 107). Весной 1944 труппа была разделена на три части: одна осталась в Германии, другую отправили на север Франции, третья часть во главе с Радловым оказалась на юге Франции, неподалеку от Тулона, в местах дислокации батальонов POA (Русской освободительной армии) (см.: Равдин 2012: 181). Актеры давали у них спектакли (см.: Золотницкий 1999: 258).

В письме от 3 января 1948, написанном в советском лагере к Чобуру, режиссер так вспоминал об этом времени: «Мы ездили по Франции, терпя лишения и неудобства, довольно редко сытые,

\footnotetext{
143 Мне рассказывала А. А. Искоз-Долинина, как 5 августа 1942 шестидесятидвухлетний профессор А. С. Долинин с женой, дочерью, невесткой и трехлетним внуком бежали от фашистов из г. Ессентуки, шли 120 км пешком, до Нальчика, только в последний день их подвезли. Для сопоставления можно напомнить об испанском «исходе» 1939 и парижском 1940.

${ }^{144} \mathrm{O}$ «Винете» см.: Петров 2016: 206-223.
} 
с плохими ночлегами, но когда нас завозили в какую-нибудь каменную южную деревушку, где стояло человек шестьдесят пленных русских конюхов, <..> когда мы играли водевили Чехова на милом для них русском языке, <..> когда сквозь решетки монастыря сияли Пиренейские горы, а между утесами сверкало неправдоподобно синее море, - это было великое утешение в наших горестях и бедах» (Гайдабура 1992: 118).

15 августа 1944 между Тулоном и Каннами началась высадка союзников, но актеры, заранее предупрежденные русскими военнопленными, успели уйти в горы и не попали под бомбардировку и обстрел корабельной артиллерии (см.: Золотницкий 1999: 260).

После освобождения Парижа в августе 1944 и возобновления деятельности советского посольства Радлов «дал знать туда о своей актерской бригаде. Пришел совет - добираться до посольства собственными средствами» (Там же: 261). Под Марселем были созданы многолюдные лагеря российских репатриантов, там радловцы и «гастролировали» около двух с половиной месяцев (см.: Там же: 262), в газетах «помещали портреты Радлова и его интервью» (Там же: 264). В январе 1945 режиссер со своими актерами приехал наконец в Париж.

По атрибуции Р. Д. Тименчика, именно Радлов был тем ленинградцем, который анонимно дал интервью парижской газете «Русский патриот», где упомянул о гибели Мандельштама: «Скончался поэт О. Э. Мандельштам (вне Ленинграда)» (Тименчик 2008: 552). Интервью было опубликовано 3 марта 1945, то есть уже после того как 23 февраля 1945 Радлов с женой возвратился в СССР, где их обоих арестовали и осудили.

Они отбывали срок в лагере в Ярославской области, под Рыбинском (который назывался тогда Щербаковым), в селе Переборы. Им позволили видеться, впоследствии они смогли жить вместе в выделенной режиссеру каморке. Сестра А. Д. Радловой С. Д. Лебедева посылала супругам все необходимое, включая книги. «Сергій Ернестович студіює англійською Шекспіра, Анна Дмитрівна втішається Вольтером французькою...» (Гайдабура 2009: 38). 
В лагерном театре Радлов ставил концерты и спектакли. 13 февраля 1946 режиссер писал сыну ${ }^{145}$ :

Мы с мамой сейчас ставим «Без вины виноватые» <...> здесь довольно сильная, хотя и очень «сборная команда». $<\ldots>$ Материала мало, я много сочиняю стихов и героических, и шутливых, сочинил сценарий маленького балета, вообще невольно вспоминаю далекие времена «Народной комедии» (цит. по: Золотницкий 1999: 269, 270).

В письме к Чобуру, написанном в конце июня - начале июля 1946, Радлов сообщал:

$<\ldots>$ Сарра Дм<итриевна $>$ помогает так энергично, что мы ни в чем не нуждаемся. Да и Митя помогает в меру своих очень скромных возможностей; но это уже совершенно необходимо не столько для нас, сколько для него (цит. по: Гайдабура 1992: 111).

Помощь сына была недолгой. Как сообщает исследователь, «страшным ударом для супругов стало отступничество нежно любимого ими сына - очень скоро он прервал с ними переписку» (Там же: 108). В 1949 умерла Анна Дмитриевна, Радлова освободили в 1953, реабилитировали 20 декабря 1957 (см.: Равдин 2012: 196).

После освобождения он поселился в Даугавпилсе. Возможно, что лишь тогда Радлов узнал о конфискации своего имущества, и в частности - домашней библиотеки. На свои запросы «в соответствующие органы» он получал ответ: «Вторично сообщаем, что Ваше имущество, оставшееся в гор. Ленинграде, после Вашей эвакуации в 1942 году, органами НКГБ при аресте Вас и жены в 1945 году не изымалось и не конфисковывалось» (Кельнер 2006: 96). Ответ был правдив: имущество конфисковали еще в 1943.

14 августа 1943 сотрудник ГПБ А. П. Могилянский сообщал в докладной записке, что он в присутствии майора госбезопасности

\footnotetext{
145 В это время Д. С. Радлов служил в Кишиневском театре, затем в театрах г. Мукачево и Таллинна. В 1953 вернулся в Ленинград, много гастролировал по СССР как чтец с сольными программами. В 1965-1969 был главным режиссером Ленинградской государственной областной филармонии, см.: Гайдабура 2009: 55.
} 
И. С. Комлякова ${ }^{146}$ осмотрел библиотеку Радловых и выяснил, что в основе библиотеки - книги по театру и классической филологии XVI-XX вв. на русском, латинском, греческом, немецком и французском языках. Среди них были, например, Comediae Плавта (1621). «Общее количество книг - три с половиной шкафа. Тов. Комляков согласен предоставить нам право приобретения выборочно" (цит. по: Кельнер 2006: 96, подчеркнуто в документе). В ГПБ перешло более двух с половиной тысяч книг и журналов, они были распределены по различным фондам библиотеки (Там же: 97).

С октября 1953 Радлов работал в городском театре Даугавпилса. 7 ноября 1953 режиссер, которому только что исполнился 61 год, писал из Минска Б. В. Казанскому ${ }^{147}$ :

$<\ldots>$ Если хватит силенок, за 54 г. поставлю три шекспировских трагедии в Даугавпилсе, Риге и Минске. А цель моей не очень-то уж веселой жизни - восстановить во всех правах чудесные переводы Анны вместо декламаций Лозинского и пастернаковского косноязычия. В Двинске мне живется очень уютно и в бытовом отношении $<\ldots>$ А я ведь в 44 году читал, что Ты, Боря, умер от голода. Не часты в жизни такие приятные неожиданности! <... $>^{148}$.

25 января 1954 Радлов писал Казанскому из Даугавпилса:

Милый Боря, <...>

Твое письмо пришло за несколько дней до сдачи мною первого моего спектакля (за 11 лет) - очень трудного и неблагодарного. Это колхозная гуцульская трагедия, начатая Я. Галаном ${ }^{149}$ и бездарно

\footnotetext{
146 У Могилевского ошибочно стоит первый инициал «Н». Иван Степанович Комляков (1899 - ?) - майор госбезопасности, старший оперуполномоченный УНКВД, член ВКП(б) с 1918, см.: [http://qps.ru/ho1NH]

${ }_{147}$ Н. Э. Казанская умерла в 1938.

148 ОР РНБ. Ф. 1393. Ед. хр. 713. Л. 16 об.

149 Ярослав Александрович Галан (1902-1949), публицист, драматург. Учился в Краковском университете, был членом компартии Западной Украины. С 1949 - кандидат в члены ВКП(б). Его памфлеты служили идеологическим обоснованием для ликвидации Украинской греко-католической церкви. По официальным сведениям убит активистом ОУН.
} 
законченная после его смерти «Любовь на рассвете» ${ }^{150}$. Против нынешних обычаев я добился разрешения, кое-что переделал сам и спас от провала последний акт. После мучительной работы спектакль я выиграл <...>

Через несколько дней после премьеры я выехал в Москву, где провел неделю у моей дорогой любимой Сарушки ${ }^{151}$. Главная цель поездки была - добиться разрешения ставить «Гамлета» (к которому я приступаю в конце февраля) в переводе Анны Радловой. $Я<,>$ конечно<,> твердо решил, что ни в каком другом переводе не буду ставить ни за что, прежде всего по мотивам лирическим, потому что я мысленно посвящаю эту работу Нюрушкиной памяти, но также и в силу моего убеждения, что ни Лозинский, ни Пастернак и в подмётки ей не годятся. Архаизмы Лозинского создают как раз то ощущение Шекспира, из-за которого Бернард Шоу говорил<,> что Шекспира спешно надо перевести с английского на английский (т. е на современный, разумеется!). А манерная и пестрая окрошка Пастернака мне просто противна. <...>

Пожалуйста, пришли мне оттиски своих статей. Это мне очень интересно! <..> Конечно, я страшно отстал от класс<ической> филологии, но Шекспиром все время немножко занимался и английским языком тоже. В сущности, у меня задумана книга о Ш<експи> ре с условным названием «Судьба Ш<експи>ра» <...> Но чувствую, что я никогда с этой задачей не справлюсь, тем более что $<1$ слово нрзб.> я сижу без библиотек, нужных для этого дела. Да и настоящую науку я все же хоть немного да понюхал в своей жизни и слишком хорошо понимаю, какой должна была бы быть такая книга, если 6 я мог посвятить ей один-два года чистого времени. $<\ldots>$

На всякий случай сообщаю, что с сыном я никаких отношений не поддерживаю и на его письмо не ответил, имея на это слишком большие основания. $<\ldots .>$

\footnotetext{
${ }_{150}$ В пьесе, опубликованной в 1951, «показана классовая борьба в послевоен<ном> западноукр<аинском> селе» (КЛЭ 1964, 2: стб. 36).

151 С. Д. Лебедевой.
} 
Обнимаю Тебя.

Твой Сережа ${ }^{152}$.

«Гамлет», разрешенный московским начальством, был сыгран в театре Даугавпилса в мае 1954 (см.: Золотницкий 1999: 278), и опять со сцены звучала клятва принца в переводе Радловой:

Век вывихнут, о злобный жребий мой,

Век вправить должен я своей рукой.

(Шекспир 1937: 52)

В июне состоялись гастроли в Риге, но перевестись в латвийскую столицу режиссером русского драматического театра Радлов смог только в январе 1955 с помощью тогдашнего замминистра культуры Латвийской ССР В. К. Калпиньша. Последний, выступая в 1988 на вечере, посвященном 30-летию со дня смерти режиссера, «говорил о том, что перевод С. Радлова в Ригу потребовал определенной работы с КГБ ЛССР» (Равдин 2012: 191).

В рижском театре русской драмы были поставлены «Король Лир», ибсеновские «Привидения», в рижском ТЮЗе - «Ромео и Джульетта» (см.: Золотницкий 1999: 285, 286). В 1957 появился последний шекспировский спектакль Радлова - «Макбет», постановка вышла неудачной, современный исследователь так высказался о ней: «Зрелище оказалось оперно-громоздким, а его пафос натужным» (Там же: 288).

Еще в Даугавпилсе Радлову посчастливилось встретить близкого человека, Надежду Романовну Бакалову, выпускницу Ленинградского педиатрического медицинского института, сохранившую его письма (подробнее см.: Равдин 2012: 193). Годы скитаний и лагеря не прошли бесследно, летом 1955 Радлов перенес инсульт $^{153}$. Он скончался 27 октября 1958.

\footnotetext{
152 ОР РНБ. Ф. 1393. Ед. хр. 713. Л. 17-18 об.

153 См.: ОР РНБ. Ф. 1393. Ед. хр. 713. Л. 21.
} 


\section{БИБЛИОГРАФИЯ}

Азадовский К. М., Тименчик Р. Д. 1988. К биографии Н. С. Гумилева (вокруг дневников и альбомов Ф. Ф. Фидлера). - Русская литература. № 2. С. 171-186.

Бердичевский Я. 2004. Еврейские книжники. Из истории людей и экслибрисов. - Егупец (Киев). № 14 [URL: http://judaica.kiev.ua/old/Eg_14/14-18. htm].

Березарк И. Б. 1940. «Гамлет» в Театре имени Ленинградского Совета. Опыт анализа спектакля / Под ред. К. Н. Державина. Л.; М.: ЛО Всероссийского театрального общества.

Блок А. А. 1965. Записные книжки. 1901-1920 / Составление, подготовка текста, предисловие и примечания В. Н. Орлова. М.: Художественная литература.

Блок А. А. 1982. Александр Блок. Новые материалы и исследования: В 5 кн. Кн. 3. М.: Наука. (Литературное наследство. Т. 92).

Богомолов Н. А. 1988. К изучению поэзии второй половины 1910-х гг. Тыняновский сборник: Третьи Тыняновские чтения. Рига: Зинатне. С. 174-183.

Богомолов Н. А. 1995. Михаил Кузмин: Статьи и материалы. М.: Новое литературное обозрение.

Богомолов Н. А. 2010. Вокруг “серебряного века”: Статьи и материалы. М.: Новое литературное обозрение.

Богомолов Н. А., Малмстад Дж. 2013. Михаил Кузмин. М.: Молодая гвардия.

Ботт М.-Л. 1989. О построении пьесы Михаила Кузмина «Смерть Нерона» (1928-1929 г.). Тема с вариациями от Мандельштама до Булгакова. Studies in the Life and Works of Mixail Kuzmin / Ed. by John E. Malmstad. Wien: [б. и.]. С. 141-151 (Wiener Slawistischer Almanach. S-Band 24).

Будницкий О. В., Полян А. Л. 2013. Русско-еврейский Берлин: 1920-1941. М.: Новое литературное обозрение.

Васильков Я. В., Сорокина М. Ю. 2003. Люди и судьбы. Биобиблиографический словарь востоковедов - жертв политического террора в советский период (1917-1991). СПб.: Петербургское востоковедение. Волков Н. Д. 1929. Мейерхольд: В 2-х тт. Т. 2. 1908-1917. М.; Л.: Academia.

Гайдабура В. М. 1992. «И наша первая любовь горит последнею любовью». - Театр. № 10. С. 101-126. 
Гайдабура В. М. 2009. «ГУЛАГ і світло театру»: Листи із зони Сергія та Анни Радлових. 1946-1953. Киев: «Факт».

Гвоздева М. Ф. 1998. Гвоздевы и Шухаевы / Вступительная ст. и публикация М. Г. Овандер. - Наше наследие. № 45. С. 87-96.

Георге С. 1911. Переводы из Стефана Георге. - Аполлон. № 3. С. 41-45.

Георге С. 2009. Седьмое кольцо / Пер. с нем. В. Летучий. М.: Водолей.

Гоголь Н. В. 1952. Собр. соч.: В 6-ти тт. Т. 2. Миргород. М.: ГИХЛ.

Голубенцев Н. 1967. Из дневника актера. - Встречи с Мейерхольдом: Сборник воспоминаний / Ред.-сост. Л. Д. Вендровская. М.: ВТО. С. 164172.

Гольденвейзер А. А. 2005. Дневники и письма разных лет / [Публикация и комментарий А. Зейде]. - Ab Imperio. 2005. № 3. С. 347-403.

Дмитриев П. В. 2009. «Аполлон» (1909-1918). Материалы из редакционного портфеля. СПб.: Балтийские сезоны.

Жирмунский В. М. 1977. Теория литературы. Поэтика. Стилистика / Издание подготовлено Н. А. Жирмунской. Л.: Наука.

Закурдаев И. В. 2013. Владимирский централ. История Владимирской тюрьмы. М.: РИПОЛ классик.

Золотницкий Д. И. 1999. Сергей Радлов: Режиссура судьбы. СПб.: РИИИ.

Иванов В. В. 2009. «Мне было завидно, что люди могут смеяться». Письма С. М. Михоэлса и С. Э. Радлова (1929-1934) / Публикация, вступительная ст. и комментарии В. В. Иванова. - Мнемозина: Документы и факты из истории отечественного театра ХХ века. Вып. 4 / Ред.-сост. В. В. Иванов. М.: Индрик. С. 506-532.

Иванова Е. В. 2012. Александр Блок: Последние годы жизни. СПб.: Росток. Испанский театр XVI-XVII вв. [1912?] Введение к спектаклям Старинного театра. 1911-1912 / Статьи Н. В. Дризена, К. [М.] Миклашевского, Н. [Н.] Евреинова. [СПб.]: Типография журнала “Сатирикон” М. Г. Корнфельда.

История советского театра 1933. История советского театра: Очерки развития. Т. 1. 1917-1921. Л.: Ленгихл.

Каганович Б. С. 2018. Александр Александрович Смирнов. 1883-1962. СПб.: Издательство «Европейский Дом».

Казанский Н. Н. 2012. Борис Васильевич Казанский. - «Эта пристань есть...». Портреты. Размышления. Воспоминания о людях и Писательском доме / Сост., предисловие, подготовка текстов к публикации, справка об авторах Т. В. Акуловой. СПб.: АураИнфо. С. 8-12. 
Казароза 1930. [Памяти Бэлы Георгиевны Казарозы] / Издано Н. Д. Волковым на правах рукописи в количестве 400 нумерованных экземпляров. М.: [б. и.].

Кельнер В. Е. 2006. Библиотека Радловых: Опыт реконструкции. Книжное дело в России в XIX - нач. XX в.: Сборник научных трудов. Вып. 13. СПб.: Российская национальная библиотека. С. 95-106.

Кельнер В. Е. 2018. Щит: М. М. Винавер и еврейский вопрос в России в конце XIX - начале XX века. СПб.: Издательство Европейского университета в Санкт-Петербурге.

Кельнер В. Е., Новикова О. П. 2005. Инскрипты литераторов и литературоведов в фондах Российской национальной библиотеки. - Новое литературное обозрение. № 74. С. 599-624.

Кертман Л. Е. 1987. Первый на Урале / Л. Е. Кертман, Н. Е. Васильева, С. Г. Шустов. Пермь: Пермское книжное издательство.

КЛЭ 1964. Краткая литературная энциклопедия: В 9-ти тт. Т. 2. М.: Советская Энциклопедия.

Книги и рукописи в собрании М. С. Лесмана 1989. Книги и рукописи в собрании М. С. Лесмана: Аннотированный каталог. Публикации / Вступительная статья Н. Г. Князевой. М.: Книга.

Кофейня разбитых сердец 1997. Коллективная шуточная пьеса в стихах при участии О. Э. Мандельштама / Публикация Т. Л. Никольской, Р. Д. Тименчика и А. Г. Меца. Stanford: Berkeley Slavic Specialties (Stanford Slavic Studies. Vol. 12).

Кузмин М. А. 2005. Дневник 1908-1915 / Подготовка текста и комментарий Н. А. Богомолова и С. В. Шумихина. СПб.: Издательство Ивана Лимбаха.

Кузмин М. А. 2007. Дневник 1934 года. 2-е изд., испр. и доп. / Под ред. Г. А. Морева. СПб.: Издательство Ивана Лимбаха.

Купцова О. Н. 2000. «...Всегда помнил Вас и всё, о чем мы с Вами говорили...». О письмах К. Н. Державина В. Э. Мейерхольду. К. Н. Державин. Письма В. Э. Мейерхольду. К. Н. Державин. Страница из истории советского театрального образования / Публикация и комментарий О. Н. Купцовой. - Мейерхольдовский сборник. Вып. 2: «Мейерхольд и другие». Документы и материалы / Ред.-сост. О. М. Фельдман. М.: О. Г. И. С. 567-611.

Куранда Е. Л. 2015. М. Кузмин и его круг в архиве Радловых в Отделе рукописей Российской национальной библиотеки. - Михаил Кузмин: 
Литературная судьба и художественная среда / Под ред. П. В. Дмитриева и А. В. Лаврова. СПб.: Реноме. С. 226-270.

Куранда Е. Л. 2016. «Знаю я теперь, что такое артиллерийские позиции»:

Письма А. М. Зельмановой к Н. Э. Казанской. - Осип Мандельштам и XXI век: Материалы международного симпозиума. Москва. 1-3 ноября 2016 г. / Ред.-сост. Л. Видгоф, Д. Зуев, О. Лекманов, П. Нерлер. М.: ООО Армполиграф. С. 89-96.

Левинтон Г. А., Устинов А. Б. 2001. Материалы о Кузмине в журнале «Гермес». - Материалы конференции, посвященной 110-летию со дня рождения академика Виктора Максимовича Жирмунского. СПб: Наука. С. 322-334.

Лекманов О. А. 2000. Книга об акмеизме и другие работы. Томск: Водолей. Летопись 2016. Летопись жизни и творчества О. Э. Мандельштама / Сост. А. Г. Мец при участии С. В. Василенко, Л. М. Видгофа, Д. И. Зубарева, Е. И. Лубянниковой, П. Мицнера. 2-е изд., испр. и доп. Toronto: TSQ. [URL: http://imwerden.de/pdf/mandelshtam_letopis_zhizni_i_tvorchestva_2izdanie_2016__ocr.pdf]

Лившиц Б. К. 1989. Полутораглазый стрелец: Стихотворения, переводы, воспоминания / Вступительная ст. А. А. Урбана, сост. Е. К. Лившиц и П. М. Нерлера, подготовка текста П. М. Нерлера и А. Е. Парниса, примечания П. М. Нерлера, А. Е. Парниса и Е. Ф. Ковтуна. Л.: Советский писатель.

Лисакова Ю. Б. 2010. «Симпатичная и оригинальная затея» [Письма Н. Н. Евреинова Н. В. Дризену; Дризен Н. В. Старинный театр (1916)] / Публикация, подготовка текста, вступительная ст. и примечания Ю. Б. Лисаковой. - Наше наследие. № 93-94. С. 76-89.

Лукницкий П. Н. 1991. Мандельштам в архиве П. Н. Лукницкого / Публикация В. К. Лукницкой, предисловие и примечания П. М. Нерлера. - Слово и судьба. Осип Мандельштам. Исследования и материалы. М.: Наука. С. 111-148.

Лукницкий П. Н. 2010. Труды и дни Н. С. Гумилева / Под общ. ред. Ю. В. Зобнина. СПб.: Наука.

Мандельштам Е. Э. 1995. Воспоминания / Публикация и примечания Е. П. Зенкевич; предисловие А. Г. Меца. - Новый мир. № 10. С. 119-178.

Мандельштам Н. Я. 1989. Воспоминания / Подготовка текста Ю. Л. Фрейдина, послесловие Н. В. Панченко, примечания А. А. Морозова. М.: Книга. 
Мандельштам Н. Я. 1990. Вторая книга / Подготовка текста, предисловие, примечания М. К. Поливанова. М.: Московский рабочий.

Мандельштам Н. Я. 2017. <Мандельштам - читатель> / Реконструкция и публикация А. Б. Устинова. - Мандельштам - читатель / Читатели Мандельштама / Сост. О. А. Лекманов, А. Б. Устинов. Stanford: Aquilon Books. C. 15-24 (Modern Russian Literature and Culture. Studies and Texts. Vol. 47).

Мандельштам О. Э. 1910. [Стихотворения]. - Аполлон. № 9. С. 5-7 (2-я пагинация).

Мандельштам О. Э. 1922. [Два стихотворения]. - Абраксас. (Ноябрь). [Сб. 2]. [Пг.]: Типография «Красный печатник». С. 17.

Мандельштам О. Э. 1990. Камень / Издание подготовили Л. Я. Гинзбург, А. Г. Мец, С. В. Василенко, Ю. Л. Фрейдин. Л.: Наука.

Мандельштам О. Э. 2009-2011. Полн. собр. соч. и писем: В 3-х тт. М.: Прогресс-Плеяда.

Мандельштам О. Э. 2014. Полн. собр. соч. и писем: В 3-х тт. Приложение: Летопись жизни и творчества. М.: Прогресс-Плеяда.

Мгебров А. А. 1932. Жизнь в театре: В 2-х тт. [Т.] II / Комментарий Э. А. Старка. М.; Л.: Academia.

Миклашевская Л. П., Катерли Н. С. 2007. Чему свидетели мы были. Женские судьбы. ХХ век / Вступительная ст. Я. А. Гордина. СПб.: ЗАО «Журнал “Звезда”».

Миклашевский К. М. 1914-1917. La commedia dell'arte, или Театр итальянских комедиантов XVI, XVII и XVIII столетий. Часть 1. СПб.: Изд. Н. И. Бутковской.

Миклашевский К. М. 1924. Гипертрофия искусства. Пг.: Государственная типография им. Е. Соколовой.

Мицнер П. 2015. Начало восприятия Мандельштама в Польше (19251947). - Корни, побеги, плоды... Мандельштамовские дни в Варшаве: В 2 ч. Ч. 1 / Сост. П. М. Нерлер, А. Поморский, И. 3. Сурат. М.: РГГУ. С. $52-60$.

Мокульский С. С. 1929. [Предисловие]. - Радлов С. Э. Десять лет в театре: Сборник статей. Л.: Прибой. С. 4-22.

Морев Г. А. 1997. Еще раз о Пастернаке и Кузмине: К истории публикации пастернаковского стихотворения «Над шабашем скал, к которым...» («Пушкин»). - Лотмановский сборник. [Вып.] 2. М.: О.Г.И. C. 363-376. 
Мочульский К. В. 1999. Письма к В. М. Жирмунскому / Вступительная ст., публикация и комментарий А. В. Лаврова. - Новое литературное обозрение. № 35. С. 117-214.

Никольская Т. Л. 1986. Эмоционалисты. - Russian Literature. 1986. Vol. XX. No 1. С. 61-70.

Никольская Т. Л. 1990. К вопросу о русском экспрессионизме. - Тыняновский сборник. Четвертые Тыняновские чтения. Рига: Зинатне. С. $173-$ 180.

Обозрение 1912. Обозрение преподавания наук на историко-филологическом факультете императорского С.-Петербургского университета в осеннем полугодии 1912 года и в весеннем полугодии 1913 года. СПб.

Обозрение 1913. Обозрение преподавания наук на историко-филологическом факультете императорского С.-Петербургского университета в осеннем полугодии 1913 г. и в весеннем полугодии 1914 г. СПб.

Обозрения 1911. Обозрения преподавания наук в императорском С.-Петербургском университете на 1911-1912 учебный год. СПб.

Орлов Ю. А. 1991. Невозвратимое прошлое. - Пермский университет в воспоминаниях современников. Вып. I / Сост. А. С. Стабровский. Пермь: Издательство Томского государственного университета. Пермское отделение. С. 20-39.

Отчет 1911. Отчет о состоянии и деятельности императорского С.-Петербургского университета за 1910 год. СПб.: Типография Б. М. Вольфа.

Отчет 1914. Отчет о состоянии и деятельности императорского С.-Петербургского университета за 1913 год. СПб.: Типография Б. М. Вольфа.

Отчет 1915. Отчет о состоянии и деятельности императорского Петроградского университета за 1914 год. Пг.: Типография Б. М. Вольфа.

Отчет 1916. Отчет о состоянии и деятельности императорского Петроградского университета за весеннее полугодие 1916 года. Пг.: Типография Б. М. Вольфа.

Панфилова Н. Н., Фельдман О. М. 2000а. «Блоковский спектакль». Рабочие записи В. Э. Мейерхольда и комментарии к ним. - Мейерхольдовский сборник. Вып. 2: «Мейерхольд и другие». Документы и материалы / Ред.-сост. О. М. Фельдман. М.: О. Г. И. С. 309-351.

Панфилова Н. Н., Фельдман О. М. 2000b. К истории Студии В. Э. Мейерхольда. 1913/1914 и 1914/1915. Свод документов. - Мейер- 
хольдовский сборник. Вып. 2: «Мейерхольд и другие». Документы и материалы / Ред.-сост. О. М. Фельдман. М.: О. Г. И. С. 352-444.

Парнис А. Е. 1991. Штрихи к футуристическому портрету О. Э. Мандельштама. - Слово и судьба: Осип Мандельштам. Исследования и материалы. М.: Наука. С. 183-204.

Пахомова А. 2017. Литературное объединение эмоционалистов в дневниках Михаила Кузмина. - Русская филология 28. Сборник научных работ молодых филологов. Тарту: Тартуский университет. С. 115-126 [URL: http://dspace.ut.ee/handle/10062/55925].

Перченок Ф. Ф. 1995. К истории Академии наук: снова имена и судьбы... In memoriam: Исторический сборник памяти Ф. Ф. Перченка / Сост. А. И. Добкин, М. Ю. Сорокина. М.; СПб.: Феникс; Atheneum. С. 141-210.

Петров И. Р. 2016. «И дух Ленина исчез с очень странным звуком»: Учреждение «Винета» и нацистская радиопропаганда против СССР. Неприкосновенный запас. № 4 (108). С. 206-223.

Петровская И. Ф., Сомина В. В. 1994. Театральный Петербург. Начало XVIII века - октябрь 1917 года. Обозрение-путеводитель. СПб.: РИИИ.

Плавт Т. М. 1915 Близнецы / Пер. С. Радлова. - Любовь к трем апельсинам. № 4-5-6-7. С. 17-116.

Протоколы 1910. Протоколы заседаний Совета императорского С.-Петербургского университета за 1909 год. № 65. СПб.: Типография Б. М. Вольфа.

Протоколы 1916. Протоколы заседаний Совета императорского Петроградского университета за 1914 год. № 70. Пг.: Типография Б. М. Вольфа.

Пяст В. А. 1997. Встречи / Сост., вступительная ст., подготовка текста и комментарий Р. Д. Тименчика. М.: Новое литературное обозрение.

Равдин Б. А. 2012. Сергей Радлов - к постановке рижской биографии. Рижский альманах. Кн. 3. Рига: ЛОРК. С. 180-202.

Радлов С. Э. 1914а. Я верю, объятья жарки, я верю, лобзанья жгучи.... Любовь к трем апельсинам. № 3. С. 8-9.

Радлов С. Э. 1914b. [Рец.] Г. Ф. Церетели. Новые комедии Менандра (Юрьев, 1914). - Любовь к трем апельсинам. № 3. С. 88-89.

Радлов С. Э. 1918. О технике греческого актера. - Сборник историкотеатральной секции. Т. 1. Пг.: Первая государственная типография. С. 1-17 (раздел 5). 
Радлов С. Э. 1922. Убийство Арчи Брейтона. - Абраксас (Ноябрь). [Сб. 2]. [Пг.]: Типография «Красный печатник». С. 51-57.

Радлов С. Э. 1927. Режиссер о художнике. - Валентина Ходасевич: Статьи М. Кузмина, Сергея Радлова, С. Мокульского, А. Мовшенсона. Л.: «Асаdemia». C. 19-29.

Радлов С. Э. 1994. Воспоминания о Театре Народной комедии / Публикация П. В. Дмитриева. - Минувшее: Исторический альманах. [Вып.] 16. М.; СПб.: Atheneum; Феникс. С. 80-101.

Радлова А. Д. 1918. Соты. Книга стихов. Пг.: Фіаметта.

Радлова-Казанская Н. Э. 1930. Работа над речью / Предисловие Адр. Пиотровского. Л.; М.: Теакинопечать.

Русские писатели 1989-2007. Русские писатели: 1800-1917. Биографический словарь. Т. 1-5. М.: Большая Российская энциклопедия.

Сальман М. Г. 2009. Сергей Радлов и Осип Мандельштам. - Миры Осипа Мандельштама. IV Мандельштамовские чтения: материалы международного научного семинара, 31 мая - 4 июня 2009 г. Пермь - Чердынь / Сост. и общая ред. Н. А. Петровой. Пермь: Пермский государственный педагогический университет. С. 292-304.

Сальман М. Г. 2010. Осип Мандельштам: Годы учения в Санкт-Петербургском университете (по материалам Центрального государственного исторического архива Санкт-Петербурга). - Russian Literature. Vol. LXVIII. No 3/4. C. 447-499.

Сальман М. Г. 2013. Несостоявшийся «Кружок для изучения поэзии» в Петербургском университете (1912). - Русская литература. № 2. С. 167172.

Сальман М. Г. 2016. К биографии Ю. Г. Оксмана (По материалам Центрального государственного исторического архива СанктПетербурга). - Slavica Revalensia. Vol. III. Таллинн: Издательство Таллиннского университета. С. 129-170.

Сальман М. Г. 2017. Линде Фридрих Михаил Фридрихович (Федор Федорович). - Мандельштамовская энциклопедия: в 2 тт. Т. 1 / Гл. ред. П. М. Нерлер, О. А. Лекманов. М.: Политическая энциклопедия. С. 311-312.

Скорочкина О. Е. 1999. «Я всегда умела быть благодарной жизни»: Интервью с Е. В. Юнгер. - Петербургский театральный журнал. № 18-19. C. 44-48.

Смирнов А. А. 2011. Письма к Соне Делонэ / Публ. и вступ. статьи Д. Малмстада и Ж.-К. Маркадэ; подгот. текста Д. Малмстада; Ком- 
ментарий Д. Малмстада при участии Ж.-К. Маркадэ. М.: Новое литературное обозрение.

Соболев А. Л. 2013. Летейская библиотека. [Т.] І. Биографические очерки. М.: Трутень.

Соболев А. Л. 2017. К биографии Константина Ляндау, друга и издателя Мандельштама. - <Мандельштам - читатель> / Реконструкция и публикация А. Б. Устинова. - Мандельштам - читатель / Читатели Мандельштама / Сост. О. А. Лекманов, А. Б. Устинов. Stanford: Aquilon Books. C. 113-152. (Modern Russian Literature and Culture. Studies and Texts. Vol. 47)

Сотрудники РНБ 1995-2003. Сотрудники Российской национальной библиотеки - деятели науки и культуры. Биографический словарь: В 3-х т. СПб.: Издательство Российской национальной библиотеки.

Старк Э. А. 1911. Старинный театр. СПб.: Н. И. Бутковская.

Старк Э. А. 1922. Старинный театр. Пг.: «Третья стража».

Струве Г. П. 1979. [Предисловие]. К истории русской поэзии 1910-х - начала 1920-х годов. - Modern Russian Literature and Culture. Studies and texts. Berkeley Slavic Specialties. Berkeley. Vol. 1. C. 13-28.

Струтинская Е. И. 2004. «Единственный в своем роде». Николай Калмаков.

- Мнемозина. Документы и факты из истории отечественного театра ХХ века. Вып. 3 / Ред.-сост. В. В. Иванов. М.: Артист. Режиссер. Театр. C. $426-471$.

Струтинская Е. И. 2009. «Настроение кошмара и маскарада...»: Письма Н. К. Калмакова А. Н. Чеботаревской. 1909-1915 / Публикация, вступительная ст. и комментарии Е. И. Струтинской. - Мнемозина: Документы и факты из истории отечественного театра XX века. Вып. 4 / Ред.-сост. В. В. Иванов. М.: Индрик. С. 302-311.

Табункина И. А. 2015. Профессор Б. А. Кржевский в Пермском университете. - Вестник Пермского университета. № 3 (31). С. 136-148.

TЭ 1965. Театральная энциклопедия: В 5-ти тт. T. IV. М.: Советская энциклопедия.

Тименчик Р. Д. 1991 Об одном письме Анны Ахматовой. - Звезда. № 9. С. $165-167$.

Тименчик Р. Д. 2008. Что вдруг. Статьи о русской литературе прошлого века. М.; Иерусалим: Мосты культуры; Гешарим.

Тименчик Р. Д. 2016. Ангелы-люди-вещи: В ореоле стихов и друзей. М.; Иерусалим: Мосты культуры; Гешарим. 
Тименчик Р. Д. 2017. Подземные классики. Иннокентий Анненский. Николай Гумилев. М.; Иерусалим: Мосты культуры; Гешарим.

Тименчик Р. Д. 2018. История культа Гумилева. М.: Мосты культуры.

Тимофеев А. Г. 1997. Вокруг альманаха Абраксас (Из материалов к истории издания). - Русская литература. № 4. С. 190-205.

Толстая М. А. 2004. К проблеме авторства перевода романа Сервантеса “Дон Кихот” для издательства “Асademia”. - Известия Академии наук. Серия литературы и языка. Т. 63. № 3. С. 56-59.

Хлебникова-Смирнова К. С. 1994. Мои воспоминания. Таллинн: “Александра" [URL: https://www.sakharov-center.ru/asfcd/auth/?t=page \&num=4937]

Черных В. А. 2008. Летопись жизни и творчества Анны Ахматовой: 18891966. 2-е изд., испр. и доп. М.: Индрик.

Чжиен Ан. 2000. Стилизация в русской драматургии начала XX века: Заметки о неопубликованных пьесах К. М. Миклашевского. - Русская литература. № 4. С. 113-150.

Чудакова М. О., Тоддес Е. А. 1981. Прототипы одного романа. - Альманах библиофила. Вып. Х. М.: Книга. С. 172-190.

Чудовский В. А. 1916. [Рец.]: Плавт. Близнецы (Menaechmi) / Пер. Сергея Радлова. - Аполлон. № 4-5. С. 87-88.

Чушкин Н. Н. 2004. В. В. Дмитриев. Творческий путь (Записи бесед, выписки, наброски и другие материалы). 1948 г. / Предисловие А. А. Михайловой. Публикация, вступительный текст и примечания Е. И. Струтинской. - Мнемозина. Документы и факты из истории отечественного театра XX века. Вып. 3 / Ред.-сост. В. В. Иванов. М.: Артист. Режиссер. Театр. С. 346-393.

Шапорина Л. В. 2011. Дневник: В 2-х тт. / Вступительная ст., подготовка текста, комментарий В. Ф. Петровой и В. Н. Сажина. М.: Новое литературное обозрение.

Шекспир В. 1937. Гамлет принц датский / Пер. Анны Радловой. Л.; М.: Искусство.

Шруба М. 2004. Литературные объединения Москвы и Петербурга 18901917. М.: Новое литературное обозрение.

Шумихин С. В. 2015. Роман с газетой: Е. М. Кузнецов на страницах Дневника М. А. Кузмина. - Михаил Кузмин. Литературная судьба и художественная среда / под ред. П. В. Дмитриева и А. В. Лаврова. СПб.: Реноме. С. 203-225. 
Яковлева Е. П. 1989. Три мастера. - Аврора. № 2. С. 146-147.

Яковлева Е. П. 1991. «Мы ваши ученики». Письма А. Е. Яковлева и В. И. Шухаева Д. Н. Кардовскому (1923-1934). - Искусство Ленинграда. № 1. C. 77-89.

Янгиров Р. М. 1996. «За революционным фронтом я плетусь в обозе 2-го разряда...». Из писем К. М. Миклашевского к деятелям театра (19141941) / Вступительная ст., публикация и примечания Р. М. Янгирова. Минувшее: Исторический альманах. [Вып.] 20. М.; СПб.: Atheneum; Феникс. С. 404-431.

Alfonso X el Sabio. 1906. Primera crónica general: Estoria de España que mando componer Alfonso el Sabio y se continuaba bajo Sancho IV en 1289 / Publ. por Ramón Menéndez Pidal. T. I. Texto. Madrid: Bailly-Bailliere e hijos.

Dozy, R. 1881. Recherches sur l'histoire et la littérature de l'Espagne pendant le moyen âge. 3-ème éd. revue et augmentée. T. I, II. Paris; Leyde: Maisonneuve \& Co; E. J. Brill.

Litotes [Н. В. Недоброво] 1916. Общества и собрания. - Аполлон. № 4-5. C. $86-87$.

Menéndez Pidal R. 1905. Manual elemental de Gramática Histórica Española. Madrid: Librería General de Victoriano Suárez.

\section{REFERENCES}

Alfonso X el Sabio. Primera crónica general: Estoria de España que mando componer Alfonso el Sabio y se continuaba bajo Sancho IV en 1289. Publ. por Ramón Menéndez Pidal. T. I, Texto. Madrid: Bailly-Bailliere e hijos, 1906.

Azadovskii, K. M. and Timenchik, R. D. "K biografii N. S. Gumileva (vokrug dnevnikov i al'bomov F. F. Fidlera).” Russkaia literatura 2 (1988): 171-186.

Berdichevskii, Ia. "Evreiskie knizhniki. Iz istorii liudei i ekslibrisov.” Egupets 14 (2004). Accessed October 31, 2018. http://judaica.kiev.ua/old/Eg_14/14-18. htm.

Berezark, I. B. "Gamlet” v Teatre imeni Leningradskogo Soveta. Opyt analiza spektaklia. Edited by K. N. Derzhavin. Leningrad and Moscow: LO Vserossiiskogo teatral'nogo obshchestva, 1940.

Blok, A. A. Zapisnye knizhki. 1901-1920. Edited and annotated by V. N. Orlov. Moscow: Khudozhestvennaia literatura, 1965.

- Aleksandr Blok. Novye materialy i issledovaniia. 5 vols. Vol 3. Moscow: Nauka, 1982. 
Bogomolov, N. A. "K izucheniiu poezii vtoroi poloviny 1910-kh gg.” In Tynianovskii sbornik Tret'i Tynianovskie chteniia, 174-83. Riga: Zinatne, 1988.

_. Mikhail Kuzmin: Stat'i i materialy. Moscow: Novoe literaturnoe obozrenie, 1995.

—. Vokrug "serebrianogo veka": Stat'i i materialy. Moscow: Novoe literaturnoe obozrenie, 2010.

Bogomolov, N. A. and Malmstad, J. Mikhail Kuzmin. Moscow: Molodaia gvardiia, 2013.

Bott, M.-L. 'O postroenii p'esy Mikhaila Kuzmina 'Smert' Nerona' (19281929 g.). Tema s variatsiiami ot Mandel'shtama do Bulgakova.” In John E. Malmstad, ed. Studies in the Life and Works of Mixail Kuzmin, 141-51. Wien: [n. p.], 1989.

Budnitskii, O. V. and Polian, A. L. Russko-evreiskii Berlin: 1920-1941. Moscow: Novoe literaturnoe obozrenie, 2013.

Chernykh, V. A. Letopis' zhizni i tvorchestva Anny Akhmatovoi: 1889-1966. 2nd ed., rev. Moscow: Indrik, 2008.

Chudakova, M. O. and Toddes, E. A. "Prototipy odnogo romana." In Al'manakh bibliofila. Vol. 10, 172-90. Moscow: Kniga, 1981.

Chudovskii, V. A. Review of Sergei Radlov's translation of Menaechemi by Plautus. Apollon 4-5 (1916): 87-88.

Chushkin, N. N. “V. V. Dmitriev. Tvorcheskii put' (Zapisi besed, vypiski, nabroski i drugie materialy). 1948 g." Introduction by A. A. Mikhailova. Published and annotated by E. I. Strutinskaia. In Ivanov, V. V., ed. Mnemozina. Dokumenty i fakty iz istorii otechestvennogo teatra XX veka. Vol. 3, 346-93. Moscow: Artist. Rezhisser. Teatr, 2004.

Dmitriev, P. V. “Apollon" (1909-1918): Materialy iz redaktsionnogo portfelia. Saint-Petersburg: Baltiiskie sezony, 2009.

Dozy, R. Recherches sur l'histoire et la littérature de l'Espagne pendant le moyen âge. 3-ème éd. revue et augmentée. T. I, II. Paris; Leyde: Maisonneuve \& Co; E. J. Brill, 1881.

Gaidabura, V. M. “I nasha pervaia liubov' gorit posledneiu liubov'iu.” Teatr 10 (1992): 101-126.

Gaĭdabura, V. M. “GULAG ì svìtlo teatru”: Listi ìz zoni Sergīia ta Anni Radlovikh. 1946-1953. Kiev: “Fakt”, 2009.

George, S. "Perevody iz Stefana George.” Apollon 3 (1911): 41-45.

_. Sed'moe kol'tso. Translated by V. Letuchii. Moscow: Vodolei, 2009. 
Gogol', N. V. Sobranie sochinenii. 6 vols. Vol. 2, Mirgorod. Moscow: GIKhL, 1952.

Gol'denveizer, A. A. “Dnevniki i pis'ma raznykh let.” Ab Imperio 3 (2005): 347403.

Golubentsev, N. "Iz dnevnika aktera.” In L. D. Vendrovskaia, ed. Vstrechi s Meierkhol'dom: Sbornik vospominanii, 164-72. Moscow: VTO, 1967.

Gvozdeva, M. F. “Gvozdevy i Shukhaevy.” Publication by M. G. Ovander. Nashe nasledie 45 (1998): 87-96.

Iakovleva, E. P. “Tri mastera.” Avrora 2 (1989): 146-47.

—. “'My vashi ucheniki': Pis'ma A. E. Iakovleva i V. I. Shukhaeva D. N. Kardovskomu (1923-1934).” Iskusstvo Leningrada 1 (1991): 77-89.

Iangirov, R. M., publ. “Za revoliutsionnym frontom ia pletus' v oboze 2-go razriada...". Iz pisem K. M. Miklashevskogo k deiateliam teatra (19141941)." In Minuvshee: Istoricheskii al'manakh. Vol. 20, 404-31. Moscow and Saint-Petersburg: Atheneum \& Feniks, 1996.

Istoriia sovetskogo teatra: Ocherki razvitiia. Vol. 1, 1917-1921. Leningrad: Lengikhl, 1933.

Ivanov, V. V., publ. “'Mne bylo zavidno, chto liudi mogut smeiat'sia'. Pis'ma S. M. Mikhoelsa i S. e. Radlova (1929-1934)" In Mnemozina: Dokumenty i fakty iz istorii otechestvennogo teatra 20 veka. Vol. 4, 506-32. Moscow: Indrik, 2009.

Ivanova, E. V. Aleksandr Blok: Poslednie gody zhizni. Saint-Petersburg: Rostok, 2012.

Ji Young, An. "Stilizatsiia v russkoi dramaturgii nachala XX veka: zametki o neopublikovannykh p'esakh K. M. Miklashevskogo.” Russkaia literatura 4 (2000): 113-50.

Kaganovich, B. S. Aleksandr Aleksandrovich Smirnov. 1883-1962. SaintPetersburg: Izdatel'stvo “Evropeiskii Dom”, 2018.

Kazanskii, N. N. Boris Vasil'evich Kazanskii. - “eta pristan' est'...”. Portrety. Razmyshleniia. Vospominaniia o liudiakh i Pisatel'skom dome. Compiled and annotated by T. V. Akulova, 8-12. Saint-Petersburg: AuraInfo, 2012.

Kel'ner, V. E. “Biblioteka Radlovykh: Opyt rekonstruktsii." In Knizhnoe delo v Rossii v XIX - nach. XX v.: Sbornik nauchnykh trudov. Vol. 13, 95-106. SaintPetersburg: Rossiiskaia natsional'naia biblioteka, 2006.

- Shchit: M. M. Vinaver i evreiskii vopros $v$ Rossii v kontse XIX - nachale $X X$ veka. Saint-Petersburg: Izdatel'stvo Evropeiskogo universiteta v SanktPeterburge, 2018. 
Kel'ner, V. E. and Novikova O. P. "Inskripty literatorov i literaturovedov v fondakh Rossiiskoi natsional'noi biblioteki." Novoe literaturnoe obozrenie 74 (2005): 599-624.

Kertman, L. E. with Vasil'eva, N. E. and Shustov, S. G. Pervyi na Urale. Perm': Permskoe knizhnoe izdatel'stvo, 1987.

Khlebnikova-Smirnova, K. S. Moi vospominaniia. Tallinn: “Aleksandra”, 1994. Accessed October 31, 2018. https://www.sakharov-center.ru/asfcd/ auth/?t=page\&num=4937.

Kratkaia literaturnaia entsiklopediia. 9 vols. Vol. 2. Moscow: Sovetskaia entsiklopediia, 1964.

Knigi i rukopisi v sobranii M. S. Lesmana: Annotirovannyi katalog. Publikatsii. Moscow: Kniga, 1989.

Kofeinia razbitykh serdets: Kollektivnaia shutochnaia p'esa $v$ stikhakh pri uchastii O. E. Mandel'shtama. Published by T. L. Nikol'skaia, R. D. Timenchik and A. G. Mets. Stanford: Berkeley Slavic Specialties, 1997.

Kuptsova, O. N., publ. “...Vsegda pomnil Vas i vse, o chem my s Vami govorili...' O pis'makh K. N. Derzhavina V. E. Meierkhol'du. K. N. Derzhavin. Pis'ma V. E. Meierkhol'du. K. N. Derzhavin. Stranitsa iz istorii sovetskogo teatral'nogo obrazovaniia”. In O. M. Fel'dman, ed. Meierkhol'dovskii sbornik. Vol. 2, "Meierkhol'd i drugie". Dokumenty i materialy, 567-611. Moscow: O. G. I., 2000.

Kuranda, E. L. “M. Kuzmin i ego krug v arkhive Radlovykh v Otdele rukopisei Rossiiskoi natsional'noi biblioteki." In Mikhail Kuzmin: Literaturnaia sud'ba i khudozhestvennaia sreda. Edited by P. V. Dmitriev and A. V. Lavrov, 226-70. Saint-Petersburg: Renome.

_. “'Znaiu ia teper', chto takoe artilleriiskie pozitsii': Pis'ma A. M. Zel'manovoi k N. e. Kazanskoi." Osip Mandel'shtam i 21 vek: Materialy mezhdunarodnogo simpoziuma. Moskva. 1-3 noiabria 2016 g. Edited by L. Vidgof, D. Zuev, O. Lekmanov, P. Nerler, 89-96. Moscow: OOO Armpoligraf, 2016.

Kuzmin, M. A. Dnevnik 1908-1915. Compiled and annotated by N. A. Bogomolov i S. V. Shumikhin. Saint-Petersburg: Izdatel'stvo Ivana Limbakha, 2005.

—. Dnevnik 1934 goda. Edited by G. A. Morev. 2nd ed., rev. Saint-Petersburg: Izdatel'stvo Ivana Limbakha, 2007.

Lekmanov, O. A. Kniga ob akmeizme i drugie raboty. Tomsk: Vodolei, 2000. 
Letopis'zhizni i tvorchestva O. E. Mandel'shtama. Edited by A. G. Mets et al. 2nd ed., rev. Toronto: TSQ, 2016. Accessed October 31, 2018. http://imwerden.de/ pdf/mandelshtam_letopis_zhizni_i_tvorchestva_2izdanie_2016_ocr.pdf.

Levinton, G. A. and Ustinov, A. B. "Materialy o Kuzmine v zhurnale Germes." In Materialy konferentsii, posviashchennoi 110-letiiu so dnia rozhdeniia akademika Viktora Maksimovicha Zhirmunskogo, 322-34. Saint-Petersburg: Nauka, 2001.

Lisakova, Iu. B., publ. “'Simpatichnaia i original'naia zateia' [Pis'ma N. N. Evreinova N. V. Drizenu; Drizen N. V. Starinnyi teatr (1916)]." Nashe nasledie 93-94 (2010): 76-89.

Litotes [N. V. Nedobrovo]. “Obshchestva i sobraniia.” Apollon 4-5 (1916): 86-87.

Livshits, B. K. Polutoraglazyi strelets: Stikhotvoreniia, perevody, vospominaniia. Leningrad: Sovetskii pisatel’, 1989.

Luknitskii, P. N., publ. “Mandel'shtam v arkhive P. N. Luknitskogo.” In Slovo i sud'ba. Osip Mandel'shtam. Issledovaniia i materialy, 111-48. Moscow: Nauka, 1991.

Luknitskii, P. N. Trudy i dni N. S. Gumileva. Edited by Iu. V. Zobnin. SaintPetersburg: Nauka, 2010.

Mandel'shtam, E. E. "Vospominaniia." Published and annotated by E. P. Zenkevich. Foreword by A. G. Mets. Novyi mir 10 (1995): 119-178.

Mandel'shtam, N. Ia. Vospominaniia. Edited by Iu. L. Freidin. Afterword by N. V. Panchenko. Annotated by A. A. Morozov. Moscow: Kniga, 1989.

- Vtoraia kniga. Edited and annotated by M. K. Polivanov. Moscow: Moskovskii rabochii, 1990.

—_. "<Mandel'shtam - chitatel'>." Reconstructed and published by A. B. Ustinov. In Modern Russian Literature and Culture. Studies and Texts. Vol. 47, 15-24. Stanford: Aquilon Books, 2017.

Mandel'shtam, O. E. “[Stikhotvoreniia].” Apollon 9 (1910): 5-7.

—. 1922. "[Dva stikhotvoreniia].” Abraksas. [Vol. 2]. (November), 17. [Petrograd]: Tipografiia "Krasnyi pechatnik".

—. Kamen'. Edited by L. Ia. Ginzburg, A. G. Mets, S. V. Vasilenko and Iu. L. Freidin. Leningrad: Nauka, 1990.

—. Polnoe sobranie sochinenii i pisem. 3 vols. Moscow: Progress-Pleiada, 20092011.

-. Polnoe sobranie sochinenii i pisem. 3 vols. [Vol. 4], Prilozhenie: Letopis' zhizni i tvorchestva. Moscow: Progress-Pleiada, 2014. 
Menéndez Pidal R. Manual elemental de Gramática Histórica Española. Madrid: Librería General de Victoriano Suárez, 1905.

Mgebrov, A. A. Zhizn'v teatre. 2 vols. [Vol.] 2. Annotated by E. A. Stark. Moscow and Leningrad: Academia, 1932.

Miklashevskaia, L. P. and Katerli N. S. Chemu svideteli my byli. Zhenskie sud'by. $X X$ vek. Foreword by Ia. A. Gordin. Saint-Petersburg: ZAO "Zhurnal Zvezda", 2007.

Miklashevskii, K. M. La commedia dell'arte, ili Teatr ital'ianskikh komediantov 16, 17 i 18 stoletii. Pt. 1. Saint-Petersburg: Izd. N. I. Butkovskoi, 1914-1917.

—. Gipertrofiia iskusstva. Petrograd: Gosudarstvennaia tipografiia im. E. Sokolovoi, 1924.

Mitsner, P. “Nachalo vospriiatiia Mandel'shtama v Pol'she (1925-1947).” In P. M. Nerler, A. Pomorskii and I. Z. Surat, ed. Korni, pobegi, plody... Mandel'shtamovskie dni v Varshave. 2 vols. Vol. 1, 52-60. Moscow: RGGU, 2015.

Mochul'skii, K. V. "Pis'ma k V. M. Zhirmunskomu." Published and annotated by A. V. Lavrov. Novoe literaturnoe obozrenie 35 (1999): 117-214.

Mokul'skii, S. S. Foreword to Desiat' let v teatre by S. E. Radlov. In Desiat' let v teatre: Sbornik statei, 4-22. Leningrad: Priboi, 1929.

Morev, G. A. "Eshche raz o Pasternake i Kuzmine: K istorii publikatsii pasternakovskogo stikhotvoreniia 'Nad shabashem skal, k kotorym...' ('Pushkin').” In Lotmanovskii sbornik. [Vol.] 2, 363-76. Moscow: O. G. I., 1997.

Nikol'skaia, T. L. “Emotsionalisty.” Russian Literature 20, no. 1 (1986): 61-70.

_. "K voprosu o russkom ekspressionizme." In Tynianovskii sbornik. Chetvertye Tynianovskie chteniia, 173-80. Riga: Zinatne, 1990.

Obozrenie prepodavaniia nauk na istoriko-filologicheskom fakul'tete imperatorskogo S.-Peterburgskogo universiteta v osennem polugodii 1912 goda $i v$ vesennem polugodii 1913 goda. Saint-Petersburg, 1912.

Obozrenie prepodavaniia nauk na istoriko-filologicheskom fakul'tete imperatorskogo S.-Peterburgskogo universiteta v osennem polugodii $1913 \mathrm{~g}$. i v vesennem polugodii $1914 \mathrm{~g}$. Saint-Petersburg, 1913.

Obozreniia prepodavaniia nauk $v$ imperatorskom S.-Peterburgskom universitete na 1911-1912 uchebnyi god. Saint-Petersburg, 1911.

Orlov, Iu. A. "Nevozvratimoe proshloe." In Permskii universitet v vospominaniiakh sovremennikov. Edited by A. S. Stabrovskii. Vol. 1, 20-39. 
Perm': Izdatel'stvo Tomskogo gosudarstvennogo universiteta. Permskoe otdelenie, 1991.

Otchet o sostoianii i deiatel'nosti imperatorskogo S.-Peterburgskogo universiteta za 1910 god. Saint-Petersburg: Tipografiia B. M. Vol’fa, 1911.

Otchet o sostoianii i deiatel'nosti imperatorskogo S.-Peterburgskogo universiteta za 1913 god. Saint-Petersburg: Tipografiia B. M. Vol'fa, 1914.

Otchet o sostoianii i deiatel'nosti imperatorskogo Petrogradskogo universiteta za 1914 god. Petrograd: Tipografiia B. M. Vol'fa, 1915.

Otchet o sostoianii i deiatel'nosti imperatorskogo Petrogradskogo universiteta za vesennee polugodie 1916 goda. Petrograd: Tipografiia B. M. Vol’fa, 1916.

Pakhomova, A. "Literaturnoe ob"edinenie emotsionalistov v dnevnikakh Mikhaila Kuzmina." In Russkaia filologiia: Sbornik nauchnykh rabot molodykh filologov. [Vol.] 28, 115-26. Tartu: Tartuskii universitet, 2017. Accessed October 31, 2018. http://dspace.ut.ee/handle/10062/55925.

Panfilova, N. N. and Fel'dman, O. M. “'Blokovskii spektakl”. Rabochie zapisi V. E. Meierkhol'da i kommentarii k nim.” In O. M. Fel'dman, ed. Meierkhol'dovskii sbornik. Vol. 2, "Meierkhol'd i drugie". Dokumenty i materialy, 309-351. Moscow: O. G. I., 2000.

—_. "K istorii Studii V. E. Meierkhol'da. 1913/1914 i 1914/1915. Svod dokumentov." In O. M. Fel'dman, ed. Meierkhol'dovskii sbornik. Vol. 2, "Meierkhol'd i drugie”. Dokumenty i materialy, 352-444. Moscow: O. G. I., 2000.

[Pamiati Bely Georgievny Kazarozy]. Izdano N. D. Volkovym na pravakh rukopisi v kolichestve 400 numerovannykh ekzempliarov. Moscow: [n. p.], 1930.

Parnis, A. E. "Shtrikhi k futuristicheskomu portretu O. E. Mandel'shtama." In Slovo i sud'ba: Osip Mandel'shtam. Issledovaniia i materialy, 183-204. Moscow: Nauka, 1991.

Perchenok, F. F. "K istorii Akademii nauk: snova imena i sud'by...” In A. I. Dobkin and M. Iu. Sorokina, ed. In memoriam: Istoricheskii sbornik pamiati F. F. Perchenka, 141-210. Moscow and Saint-Petersburg: Feniks \& Atheneum, 1995.

Petrov, I. R. “'I dukh Lenina ischez s ochen' strannym zvukom': Uchrezhdenie 'Winieta' i natsistskaia radiopropaganda protiv SSSR." Neprikosnovennyi zapas 108, no. 4 (2016): 206-23.

Petrovskaia, I. F., Somina V. V. Teatral'nyi Peterburg. Nachalo XVIII veka oktiabr' 1917 goda. Obozrenie-putevoditel'. Saint-Petersburg: Rossiiskii Institut Istorii Iskusstv, 1994. 
Piast, V. A. Vstrechi. Edited and annotated by R. D. Timenchik. Moscow: Novoe literaturnoe obozrenie, 1997.

Plavt [Plautus], T. M. “Bliznetsy.” Translated by S. Radlov. Liubov' k trem apel'sinam 4-5-6-7 (1915): 17-116.

Protokoly zasedanii Soveta imperatorskogo S.-Peterburgskogo universiteta za 1909 god. № 65. Saint-Petersburg: Tipografiia B. M. Vol’fa, 1910.

Protokoly zasedanii Soveta imperatorskogo Petrogradskogo universiteta za 1914 god. № 70. Petrograd: Tipografiia B. M. Vol’fa, 1916.

Radlov, S. E. "Ia veriu, ob"iat'ia zharki, ia veriu, lobzan'ia zhguchi...." Liubov' $k$ trem apel'sinam 3 (1914): 8-9.

—. "Review of Novye komedii Menandra by G. F. Tsereteli." Liubov' k trem apel'sinam 3 (1914): 88-89.

_. "O tekhnike grecheskogo aktera." In Sbornik istoriko-teatral'noi sektsii. Vol. 1, 1-17. Petrograd: Pervaia gosudarstvennaia tipografiia, 1918.

—. "Ubiistvo Archi Breitona." Abraksas. [Vol. 2]. (November), 51-57. [Petrograd]: Tipografiia "Krasnyi pechatnik", 1922.

_. "Rezhisser o khudozhnike." In Valentina Khodasevich: Stat'i M. Kuzmina, Sergeia Radlova, S. Mokul'skogo, A. Movshensona, 19-29. Leningrad: Academia, 1927.

—. "Vospominaniia o Teatre Narodnoi komedii." Published by P. V. Dmitriev. In Minuvshee: Istoricheskii al'manakh. [Vol.] 16, 80-101. M.; SaintPetersburg: Atheneum; Feniks, 1994.

Radlova, A. D. Soty. Kniga stikhov. Petrograd: Fiametta, 1918.

Radlova-Kazanskaia, N. E. Rabota nad rech'iu. Foreword by Adr. Piotrovskii. Leningrad and Moscow: Teakinopechat', 1930.

Ravdin, B. A. “Sergei Radlov - k postanovke rizhskoi biografii.” In Rizhskii al'manakh. Vol. 3. Riga: LORK, 2012.

Russkie pisateli: 1800-1917. Biograficheskii slovar'. Vols. 1-5. Moscow: Bol'shaia Rossiiskaia entsiklopediia, 1989-2007.

Sal'man, M. G. “Sergei Radlov i Osip Mandel'shtam.” In N. A. Petrova, ed. Miry Osipa Mandel'shtama. IV Mandel'shtamovskie chteniia: materialy mezhdunarodnogo nauchnogo seminara, 31 maia - 4 iiunia 2009 g. Perm' Cherdyn', 292-304. Perm': Permskii gosudarstvennyi pedagogicheskii universitet, 2009.

—_. “Osip Mandel'shtam: Gody ucheniia v Sankt-Peterburgskom universitete (po materialam Tsentral'nogo gosudarstvennogo istoricheskogo arkhiva Sankt-Peterburga).” Russian Literature 48, no. 3-4 (2010): 447-499. 
—. 'Nesostoiavshiisia 'Kruzhok dlia izucheniia poezii' v Peterburgskom universitete (1912)." Russkaia literatura 2 (2013): 167-172.

—. "K biografii Iu. G. Oksmana (Po materialam Tsentral'nogo gosudarstvennogo istoricheskogo arkhiva Sankt-Peterburga)." Slavica Revalensia 3 (2016): 129-170.

—. "Linde Fridrikh Mikhail Fridrikhovich (Fedor Fedorovich)." In Mandel'shtamovskaia entsiklopediia. 2 vols. Vol. 1, 311-12. Moscow: Izdatel'stvo "Politicheskaia entsiklopediia", 2017.

Shaporina, L. V. Dnevnik. 2 vols. Moscow: Novoe literaturnoe obozrenie, 2011. Shekspir [Shakespeare], V. Gamlet prints datskii. Translated by Anna Radlova. Leningrad and Moscow: Iskusstvo, 1937.

Schruba, M. Literaturnye ob"edineniia Moskvy i Peterburga 1890-1917. Moscow: Novoe literaturnoe obozrenie, 2004.

Shumikhin, S. V. "Roman s gazetoi: E. M. Kuznetsov na stranitsakh Dnevnika M. A. Kuzmina." In P. V. Dmitriev and A. V. Lavrov, ed. Mikhail Kuzmin. Literaturnaia sud'ba i khudozhestvennaia sreda, 203-25. Saint-Petersburg: Renome, 2015.

Skorochkina, O. E. “'Ia vsegda umela byt' blagodarnoi zhizni': Interv'iu s E. V. Iunger." Peterburgskii teatral'nyi zhurnal 18-19 (1999): 44-48.

Smirnov, A. A. Pis'ma k Sone Delone. Published and annotated by John Malmstad and Jean-Claude Marcadé. Moscow: Novoe literaturnoe obozrenie, 2011.

Sobolev, A. L. Leteiskaia biblioteka. [Vol.] 1, Biograficheskie ocherki. Moscow: Truten', 2013.

—. 2017. "K biografii Konstantina Liandau, druga i izdatelia Mandel'shtama." In Modern Russian Literature and Culture. Studies and Texts. Vol. 47, 11352. Stanford: Aquilon Books, 2017.

Sotrudniki Rossiiskoi natsional'noi biblioteki - deiateli nauki i kul'tury. Biograficheskii slovar'. 3 vols. Saint-Petersburg: Izdatel'stvo Rossiiskoi natsional'noi biblioteki, 1995-2003.

Stark, E. A. Starinnyi teatr. Saint-Petersburg: N. I. Butkovskaia, 1911.

—. Starinnyi teatr. Petrograd: "Tret'ia strazha”, 1922.

Strutinskaia, E. I. “Edinstvennyi v svoem rode'. Nikolai Kalmakov.” In Ivanov, V. V., ed. Mnemozina. Dokumenty i fakty iz istorii otechestvennogo teatra XX veka. Vol. 3, 426-71. Moscow: Artist. Rezhisser. Teatr, 2004.

Strutinskaia, E. I., publ. “'Nastroenie koshmara i maskarada...’: Pis'ma N. K. Kalmakova A. N. Chebotarevskoi. 1909-1915.” In Ivanov, V. V., ed. Mnemozina. 
Dokumenty i fakty iz istorii otechestvennogo teatra XX veka. Vol. 4, 302-11. Moscow: Indrik, 2009.

Struve, G. P. “[Predislovie]. K istorii russkoi poezii 1910-kh - nachala 1920-kh godov." In Modern Russian Literature and Culture. Studies and texts. Vol. 1, 13-28. Berkeley: Berkeley Slavic Specialties, 1979.

Tabunkina, I. A. "Professor B. A. Krzhevskii v Permskom universitete." Vestnik Permskogo universiteta 31, no. 3 (2015): 136-48.

Teatral'naia entsiklopediia. 5 vols. Vol. 4. Moscow: Sovetskaia entsiklopediia, 1965.

Timenchik, R. D. “Ob odnom pis’me Anny Akhmatovoi.” Zvezda 9 (1991): 16567.

- Chto vdrug. Stat'i o russkoi literature proshlogo veka. Moscow and Jerusalem: Mosty kul'tury \& Gesharim, 2008.

- Angely-liudi-veshchi: V oreole stikhov i druzei. Moscow and Jerusalem: Mosty kul'tury \& Gesharim, 2016.

-. Podzemnye klassiki. Innokentii Annenskii. Nikolai Gumilev. Moscow and Jerusalem: Mosty kul'tury \& Gesharim, 2017.

—. Istoriia kul'ta Gumileva. Moscow: Mosty kul'tury, 2018.

Timofeev, A. G. "Vokrug al'manakha Abraksas (Iz materialov k istorii izdaniia)." Russkaia literatura 4 (1997): 190-205.

Tolstaia, M. A. "K probleme avtorstva perevoda romana Servantesa 'Don Quixote' dlia izdatel'stva 'Academia'. Izvestiia Akademii nauk. Seriia literatury i iazyka 63, no. 3 (2004): 56-59.

Vasil'kov, Ia. V. and Sorokina M. Iu., ed. Liudi i sud'by. Biobibliograficheskii slovar' vostokovedov - zhertv politicheskogo terrora v sovetskii period (19171991). Saint-Petersburg: Peterburgskoe vostokovedenie, 2003.

Volkov, N. D. Meierkhol'd. 2 vols. Vol. 2, 1908-1917. Moscow and Leningrad: Academia, 1929.

Zakurdaev, I. V. Vladimirskii tsentral. Istoriia Vladimirskoi tiur'my. Moscow: RIPOL klassik, 2013.

Zhirmunskii, V. M. Teoriia literatury. Poetika. Stilistika. Compiled by N. A. Zhirmunskaia. Leningrad: Nauka, 1977.

Zolotnitskii, D. I. Sergei Radlov: Rezhissura sud'by. Saint-Petersburg: Rossiisii institut istotrii iskusstv, 1999. 